\title{
Peroxidase enzymes as green catalysts for bioremediation and biotechnological applications: a review
}

Kheireddine Sellami ${ }^{\mathrm{a}, \mathrm{b}^{*}}$, Annabelle Couvert $^{\mathrm{b}}$, Noureddine Nasrallah ${ }^{\mathrm{a}}$, Rachida Maachi $^{\mathrm{a}}$, Mahmoud Abouseoud ${ }^{\mathrm{a}, \mathrm{c}}$, Abdeltif Amrane ${ }^{\mathrm{b}}$

a Laboratoire de Génie de la Réaction, Faculté de Génie Mécanique et Génie des Procédés, Université des Sciences et de la Technologie Houari Boumediene, Bab Ezzouar, Alger 16111, Algeria

bUniv Rennes, Ecole Nationale Supérieure de Chimie de Rennes, CNRS, ISCR (Institut des Sciences Chimiques de Rennes)-UMR 6226, F-35000 Rennes, France

CLaboratoire de Biomatériaux et Phénomènes de Transport, Faculté des Sciences et de la Technologie, Université Yahia Fares de Médéa, Pôle Universitaire, RN1, Médéa 26000, Algeria *Corresponding author: USTHB, Equipe Génie de la réaction, BP 32 Bab Ezzouar, 16111 Alger, Algérie. ENSCR, Equipe CIP, UMR CNRS 6226 ISCR, 11 allée de Beaulieu, F-35000 Rennes, France. Phone (+213) 796 598227 ; email : kheireddine.sellami.usthb@gmail.com/ORCID : 0000-0001-8581-916X 


\section{Abstract}

The fast-growing consumer demand drives industrial process intensification, which subsequently creates a significant amount of waste. These products are discharged into the environment and can affect the quality of air, degrade water streams, and alter soil characteristics. Waste materials may contain polluting agents that are especially harmful to human health and the ecosystem, such as the synthetic dyes, phenolic agents, polycyclic aromatic hydrocarbons, volatile organic compounds, polychlorinated biphenyls, pesticides and drug substances. Peroxidases are a class oxidoreductases capable of performing a wide variety of oxidation reactions, ranging from reactions driven by radical mechanisms, to oxygen insertion into $\mathrm{C}-\mathrm{H}$ bonds, and two-electron substrate oxidation. This versatility in the mode of action presents peroxidases as an interesting alternative in cleaning the environment. Herein, an effort has been made to describe mechanisms governing biochemical process of peroxidase enzymes while referring to $\mathrm{H}_{2} \mathrm{O}_{2}$ /substrate stoichiometry and metabolite products. Plant peroxidases including horseradish peroxidase (HRP), soybean peroxidase (SBP), turnip and bitter gourd peroxidases have revealed notable biocatalytic potentialities in the degradation of toxic products. On the other hand, an introduction on the role played by ligninolytic enzymes such as manganese peroxidase $(\mathrm{MnP})$ and lignin peroxidase $(\mathrm{LiP})$ in the valorization of lignocellulosic materials is addressed. Moreover, sensitivity and selectivity of peroxidase-based biosensors found use in the quantitation of constituents and the development of diagnostic kits. The general merits of peroxidases and some key prospective applications have been outlined as concluding remarks.

Keywords: Hazardous contaminant; Biodegradation; Renewable biocatalyst; Biosensor; Biofuel. 


\section{Contents}

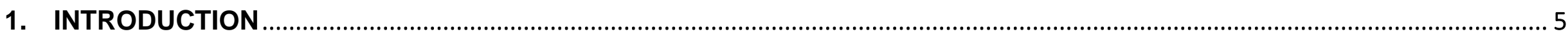

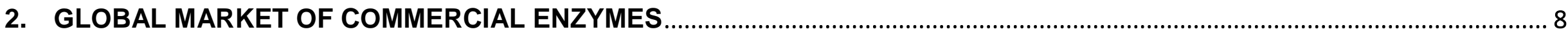

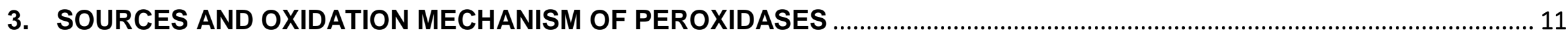

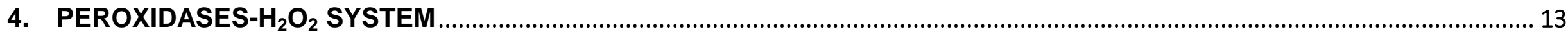

5. POTENTIAL USE OF PEROXIDASES IN ORGANIC COMPOUNDS DEGRADATION AND THEIR BIO-SENSING ................. 14

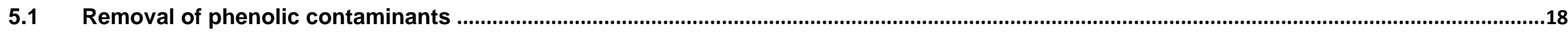

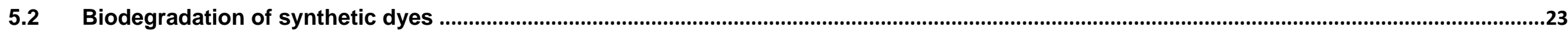

5.3 Biotransformation of pharmaceutically active compounds (PhACs) and pesticide products ............................................................................26

5.4 Bio-oxidation of polycyclic aromatic hydrocarbons (PAHs) and polychlorinated biphenyls (PCBs) molecules ...................................................31

5.5 Treatment of odorant substances and hydrophobic volatile organic compounds (VOCs) ……........................................................................35

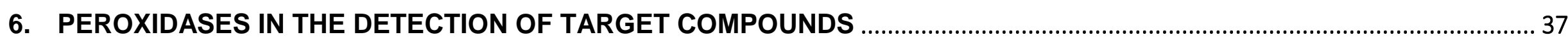

7. THE POSSIBLE ROLE OF PEROXIDASES IN THE TRANSITION FROM FOSSIL FUELS TO BIOFUELS ............................ 39

8. CONCLUSION

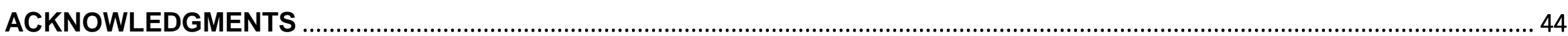


REFERENCES 


\section{Introduction}

The proliferation of industries in different sectors leads to the generation of hazardous organic compounds and hardly decomposable waste. The perpetual release of these toxic substances into water, air and soil without adequate waste management systems leads inevitably to a degradation of our ecosystem quality and endangers human health. These contaminants come from various production processes including pharmaceutical industry, petrochemical refineries, textile factories, dye and chemical manufacturing (Liu et al., 2020; Rasheed et al., 2019). Numerous studies have been carried out on a multitude of dangerous compounds including Polycyclic Aromatic Hydrocarbons (PAHs). More than 400 kinds of PAHs and their ramifications have been identified of which 16 are categorized as priority contaminants by the US Environmental Protection Agency (EPA) (Mojiri et al., 2019). PAHs are chemical molecules showing a preference for fats, favoring attachment to organic matter and insoluble in water, which makes them lipophilic and hydrophobic. These characteristics lead to an accumulation of PAHs in soils and sediments, thus becoming less bio-available and therefore difficult to biodegrade (Kronenberg et al., 2017). For instance, based on its proven toxicity, phenanthrene is referenced in the list of 16 PAHs considered as priority pollutants by the US EPA. Generally present in natural waters at concentration levels around $\mathrm{pg} \mathrm{L}^{-1}$ and not exceeding $\mathrm{ng} \mathrm{L}^{-1}$, it is however often found at concentrations ranging from $7.6 \mu \mathrm{g} \mathrm{L}^{-1}$ to $9.9 \mu \mathrm{g} \mathrm{L}^{-1}$ in wastewater from petroleum refineries (Wang et al., 2019). Similarly, the atmosphere is also affected by the pollution problem and for this reason, the European Commission (EC) legislations and regulations on air quality and waste air treatment are more prevalent in terms of management and control industrial waste (Tandjaoui et al., 2019). A large number of Volatile Organic Compounds (VOCs) 
constitute a significant part of air pollution and are directly responsible for greenhouse effect, stratospheric ozone depletion and photochemical smog (Zhang et al., 2017). Globally, pollution affects all media constituting the environment by causing an ecological imbalance in nature, which leads directly or indirectly to undesirable consequences on human health and the ecosystem (Anderson et al., 2012; Schwarzenbach et al., 2010). Table 1 summarizes the sources and health effects of some typical contaminants.

In order to protect the receiving environment, many wastewater treatment processes are implemented to reduce the impact of hazardous organic compounds, such as physical adsorption, extraction or chemical oxidation. However, these conventional methods exhibit certain drawbacks like, for example, low efficiency, high cost and limited stability of the process and generation of toxic by-products that are harmful to human health (Bilal et al., 2017a; Rasheed et al., 2019). The biological approach appears to be a viable and cost-effective alternative for the treatment of industrial wastewater (Villegas et al., 2016). It requires the use of bacteria, algae, fungi and enzymes for the biological degradation of toxic compounds via aerobic, anaerobic processes, or even a combination of both of them (Speight, 2017). The advantages, limitations and development stage of different treatment processes are outlined in Table 2.

However, the enzymatic treatment differs from the various biological protocols by its ease of implementation, a higher reaction velocity and seems to be and ecological method. In addition, the use of enzymes offers more advantages in terms of specificity and selectivity but also a better capacity for converting complex chemical structures (Bódalo et al., 2006; Gholami-Borujeni et al., 2011). Therefore, this technique offers new perspectives for wastewater treatment by meeting 
environmental and sustainable development requirements. Among various enzymes, peroxidases have the ability to catalyze the oxidation of various chemical compounds using hydrogen peroxide as a co-substrate (Husain, 2010; Pradeep et al., 2015). These biological catalysts have immense industrial potential and have found application in multiple biotechnological fields such as, biosensors but also in bioremediation, for example the elimination of synthetic dyes from textile industry and the polymerization of phenolic compounds (Bilal et al., 2017a; Gholami-Borujeni et al., 2011; Sellami et al., 2021; Thenmozhi \& Narayanan, 2017). Despite the effectiveness of peroxidases in hazardous compounds degradation, an application on an industrial scale cannot be envisaged in a free form, which is often associated with a lack of operational and storage stability. In order to overcome these drawbacks, enzymatic engineering has devoted special attention to the conditioning and immobilization of this protein structure (Devi et al., 2021). In extreme conditions of $\mathrm{pH}$ and temperature, the immobilization preserves the free enzyme from denaturation. Moreover, Insolubilization gives more interesting mechanical and biochemical properties with an improvement of the efficiency and stability of the biocatalyst. In addition, the immobilized enzymes offer more advantages, including a reduction in the reaction time, help to minimize microbial contamination, and probably the most important features for large scale application, an easy separation of the biological catalyst from the reaction medium and the ability to operate continuously (Bilal et al., 2017a; Bilal et al., 2018a; Sellami et al., 2021). It is obvious that the application of peroxidases for environmental and biotechnological purposes is a topical research area. This work presented in the form of a review, summarizes recent studies using peroxidase as a biological catalyst on wide range of potentially dangerous compounds for the bioremediation of different media. The contaminants 
that can be treated by peroxidases, their distribution, source and the consequences related to their release into the nature are illustrated in Fig. 1.

\section{Global market of commercial enzymes}

Biotechnology plays a significant role in the current technological revolution, particularly in terms of energy consumption and waste production, which are less important compared to conventional processes. In addition, this transition to a sustainable bio-economy will prevent pollution at source and obtain clean industrial products and processes. Industrial biotechnologies exploit the properties of enzymes, their specificity, their efficiency as well as their diversity for various industrial applications such as food industry, textile industry, detergent industry, paper and pulp industry, animal feed industry, biofuel industry and personal care product (Singhania et al., 2015). The growing need for sustainable solutions had led to an increasing demand for industrial enzymes. Currently, enzymes and whole microbial cells are used as catalysts in about 150 industrial processes. Furthermore, enzymatic biocatalysis process is involved in the manufacture of more than 500 industrial products (Adrio \& Demain, 2014; Kumar \& Singh, 2013).

In order to meet market needs, large-scale commercial enzyme production has been carried out from the fermentation of bacteria or fungi. This manufacturing process requires gentle and tightly controlled conditions but also involves several steps, including (Leisola et al., 2002):

- Selection of an enzyme;

- Selection of a production strain;

- Genetic modification of the selected strain into an overproducing strain;

- Development of production conditions and optimization of the culture medium; 
- Optimization of recovery process;

- Formulation of a final product from an enzyme concentrate, by adding preservatives, stabilizers, standardizing agents and salts.

Few industries have the technology and skills to develop commercial enzymes, which makes the global industrial enzymes market highly competitive. It is mainly led by Novozymes company, followed by DSM and DuPont (after having acquired the majority of Danisco's shares including its Genencor division) (Li et al., 2012). This increased competition is boosted by several factors, in particular the capacity for innovation and the desire to offer high-performance and quality products. Major producers of enzymes have been relatively concentrated in few developed European countries such as Denmark, Switzerland, Germany, and Netherlands but also in North America (USA). However, the pace development encountered in the AsiaPacific region suggests that Chinese, Japanese and Indian companies will join this small circle of countries producing enzymes for industrial applications with the possibility of becoming world leaders in the near future in this sector.

In 2012, global industrial market for enzymes was valued at 4.5 billion USD and was expected to reach 4.8 billion USD by 2013. According to BCC research report, global industrial enzymes market was estimated nearly 4.6 billion USD in 2014 and 4.9 billion USD in 2015 . The market of industrial enzymes was projected to grow by $4 \%$ annually to reach about 6.4 billion USD in 2021 . This market is expected to register a compound annual growth rate (CAGR) of $6.3 \%$ during the forecast period (20212026), growing to over 8.7 billion USD for the 2026 (Global Markets for Enzymes in Industrial Applications 2021-2026).

The majority of currently used industrial enzymes are hydrolytic in action, including lipases and proteases, which remain the dominant enzyme type used in the 
detergent, dairy and chemical industries (Singh et al., 2016). Various carbohydrases, primarily amylases and cellulases, used in starch, textile, detergent and baking industries, represent the second largest group (Zhu et al., 2011). In addition to these two major categories, oxidoreductases and more particularly peroxidases have enjoyed remarkable interest on an industrial scale. Indeed HRP has been widely used for the manufacture and development of enzyme-linked immunosorbent assay (ELISA) kits (Singh et al., 2019). This method makes it possible to evaluate the presence of antigens or antibodies in a sample via a reaction catalyzed by an enzyme, which releases a colored component quantified by spectroscopy. It is considered as an effective tool for the detection of the human immunodeficiency virus (HIV) responsible for the acquired immunodeficiency syndrome (AIDS), it is also a practical means used for the identification of human immunoglobulin $\mathrm{G}$ (igG) and immunoglobulin M (igM) antibodies against SARS-CoV2 in human serum or plasma. These biocatalysts are gaining additional consideration in the enzyme market due to a strong potential for exploitation in industrial waste bioremediation. For instance, bioconversion of organic compounds is only performed at laboratory scale, including the degradation of synthetic dyes, the removal of phenolic compounds and several other dangerous chemicals (Krainer \& Glieder, 2015). However, certain constraints linked to the low solubility of these substances in water and the inactivation of peroxidases by peroxides are hindering the move to a large scale. An improvement in the stability of peroxidases through genetic engineering, medium engineering and immobilization is necessary for an industrial scale extrapolation. 


\section{Sources and oxidation mechanism of peroxidases}

Peroxidases (EC 1.11.1.X) have been classified into two main categories, heme and non heme-containing enzymes. Heme is a complex between an iron ion $\left(\mathrm{Fe}^{3+}\right)$ and the molecule protoporphyrin IX. This type of enzymes have a molecular weight ranging from 30000 to $150000 \mathrm{Da}$. As stated by PeroxiBase database, $74 \%$ of the peroxidase protein sequences were identified to be heme peroxidases and mainly found in plants, fungi, bacteria and animals. In addition, $87 \%$ of known heme peroxidases are reported as non-animal origin. On the basis of sequence homologies, non-animal peroxidases are categorized into three classes namely, class I, II and III (Passardi et al., 2007a). Class I was determined as incorporating principally ascorbate peroxidase, yeast cytochrome $\mathrm{c}$ and bacterial catalaseperoxidases. They turned out to be necessary in scavenging and elimination of intracellular hydrogen peroxide (Passardi et al., 2007b). Extracellular Class II heme peroxidase, includes lignin peroxidase (LiP), manganese peroxidase $(\mathrm{MnP})$ and versatile peroxidase (VP). They showed a potential for lignin degradation derived from plants. The involvement of LiP in the oxidation of various aromatic nonphenolic lignin compounds occurs through various enzymatic reactions including side-chain cleavages, ring-opening reactions, demethoxylations and oxidative dechlorinations (Conesa et al., 2002). The typical LiP reaction is a redox process comprising one oxidation and two reduction steps. As a first step, Compound I (oxo-ferryl intermediate [ $\mathrm{Fe}(\mathrm{IV})]$ ) is formed via the action of $\mathrm{H}_{2} \mathrm{O}_{2}$ on the native enzyme LiP-Fe (III) by a two-electron oxidation. Compound I is then reduced by a reducing substrate (A) to form compound II. Finally, compound II is restored to its initial state with an electron gain to the reducing substrate (Choinowski et al., 1999). According to 
recent studies, LiPs have been compared to other peroxidases for their ability to oxidize lignin without mediator and were found to have a high redox potential $(1.2 \mathrm{~V}$ at $\mathrm{pH}$ 3) (Ertan et al., 2012). Similarly, manganese peroxidase follows the same reaction mechanism as that adopted by LiP during the peroxidative cycle. However, MnPs act differently on lignin and phenolic lignin by the oxidation of $\mathrm{Mn}^{2+}$ to $\mathrm{Mn}^{3+}$. Then, $\mathrm{Mn}^{3+}$ ions form a complex with organic acids also secreted by the fungus to finally oxidize the phenolic compounds in lignin to phenoxy radicals (Passardi et al., 2007b). Another group of class II peroxidases family, versatile peroxidases share a hybrid characteristics bringing together those of LiP and MnP. VPs exhibited oxidation ability for phenolic and non-phenolic dimers, and aromatic alcohols (Camarero et al., 1999).

Class III peroxidases are widely present in plant kingdom and account for almost $70 \%$ of the total plant-derived peroxidases (Bakalovic et al., 2006). Different sources belonging to this group of peroxidases have been the subject of several studies in the context of environmental bioremediation, such as, horseradish peroxidase (HRP) (Bilal, Rasheed, et al., 2019), soybean peroxidase (SBP) (Mashhadi et al., 2019). With a very similar structure to that class II peroxidases, plant secreted peroxidases are also involved in the hydroxylation of an important number of various chemical structures which differ from the peroxidative cycle (Liszkay et al., 2003). Once $\mathrm{H}_{2} \mathrm{O}_{2}$ react with the heme of peroxidase in native state, an intermediate comprising an oxoferryl Fe (IV) center and a cationic radical porphyrin is generated, called compound I. The next step in the catalytic cycle is the formation of compound II and free radical from a reducing substrate. Compound II is then returned to the resting state of the enzyme by the reduction of a second molecule of the substrate (Henriksen et al., 1999). Reaction of excess hydrogen peroxide with resting state enzyme gives 
compound III which is a catalytically inactive intermediate. Some recent reports regarding the role of peroxidases from different sources are listed in Table 3.

\section{Peroxidases- $\mathrm{H}_{2} \mathrm{O}_{2}$ system}

The use of hydrogen peroxide is diverse and multiple. It is employed as a preventing infection agent, bio-decontaminant and sterilizing agent widely adopted in food industry and pharmaceutical production (Chen et al., 2013). In addition, $\mathrm{H}_{2} \mathrm{O}_{2}$ is involved in many biological processes, intracellular pathways, and plays an important role in transduction of the defense signal in plants (Apostol et al., 1989). Hydrogen peroxide also participates in the catalytic reactions of peroxidases as well as oxidant and mediator for the enzymatic transformation of organic reactants. This function occupied by $\mathrm{H}_{2} \mathrm{O}_{2}$ makes peroxidases dependent to this essential co-substrate in their catalytic cycle; therefore, improper handling of this oxidizing agent affects the operational stability of the enzyme. Indeed, several studies have shown that enzyme inactivation occurs according to two distinct pathways, the first is related to the excess of $\mathrm{H}_{2} \mathrm{O}_{2}$ in the reaction medium (Van Deurzen et al., 1997), and the second consists of an attack by radical intermediates generated during substrate oxidation (Ward et al., 2001). For that reason, maintaining $\mathrm{H}_{2} \mathrm{O}_{2}$ at low concentrations is required to keep a stable catalytic activity of the enzyme, which leads to an increase of conversion rate while organic compounds transformation. To this end, two methods are used to ensure that the amount of $\mathrm{H}_{2} \mathrm{O}_{2}$ in the medium remains at low levels, a gradual addition of $\mathrm{H}_{2} \mathrm{O}_{2}$ adjusted according to the progress of the reaction or by an in situ generation of $\mathrm{H}_{2} \mathrm{O}_{2}$ (Van De Velde et al., 2001). A study devoted to the oxidation of indole to oxindole using chloroperoxidase enzyme, has shown that a feed-on-demand addition of $\mathrm{H}_{2} \mathrm{O}_{2}$ resulted in an increase of the total turnover number and space-time yield by 20 times (Seelbach et al., 1997). Similarly, operational 
stability of peroxidase was improved by generating hydrogen peroxide in situ using a bi-enzymatic system. Glucose is oxidized by glucose oxidase (GOD) with formation of $\mathrm{H}_{2} \mathrm{O}_{2}$ that is subsequently used by chloroperoxidase to oxidize thioanisole; this approach enhanced the total turnover number by twice for this reaction (Van De Velde et al., 2000). Recently, an application of immobilized horseradish peroxidase for phenol degradation was conducted. The work indicated that an excessive addition of $\mathrm{H}_{2} \mathrm{O}_{2}$ dose slowed down enzymatic catalysis by inhibition, which led to a decrease in phenol removal efficiency (Ai et al., 2016). The same observation was made in a study that investigated biodegradation of 2,4-dichlorophenol by immobilized HRP. The results showed that an optimal molar ratio $\left(\left[\mathrm{H}_{2} \mathrm{O}_{2}\right] /\right.$ [substrate] $\left.=1\right)$ gave a better conversion efficiency (Wang et al., 2015). In summary, the concentration of hydrogen peroxide in a reaction catalyzed by peroxidases depends on the nature of the reaction medium, the chemical structure of the substrate and its initial concentration.

\section{Potential use of peroxidases in organic compounds degradation and} their bio-sensing

The implementation of alternative solutions to reduce the quantity of waste discharged into the environment has become a necessity. In this context, enzymatic transformation aroused a growing interest in the design of innovative processes known as "eco-process", offered an interesting option to succeed chemical catalysts and switch to biological catalysts capable to convert very complex molecules under moderate conditions (Shakerian et al., 2020; StadImair et al., 2018). A wide range of enzymes from plants or micro-organisms have contributed significantly to the treatment and remediation of various organic compounds (Husain, 2006). Peroxidases embody and assume this role of biocatalyst exploited for environmental 
purposes by biotechnological industries. These protein structures participate to the oxidation/precipitation of hazardous contaminants for their elimination; make them biodegradable and allow their conversion to value-added products for certain applications (Chen \& Wan, 2017). The technical reason that enzymatic bioremediation has not been used on an industrial scale is essentially due to the functional instability of free enzymes under unfavorable conditions. Other obstacles hamper the exploitation of native enzymes in a treatment process, namely the inability to recover and reuse the biological catalyst. Therefore, enzyme engineering contributed significantly to the development and design of enzyme structures with optimized and improved performance. So far, immobilization has been studied in its various forms, including adsorption on a carrier (support) (Quilles Junior et al., 2016), covalent attachment to a support (Besharati Vineh et al., 2018), encapsulation in a carrier (Bilal et al., 2018b), and cross-linking (carrier-free) (Sellami et al., 2021; Tandjaoui et al., 2015).

Physical adsorption of enzymes on the surface of porous materials takes place via reversible interactions that include hydrogen bonds, van der Waals forces and ionic interactions (Hanefeld et al., 2009). This approach does not require any chemical reaction and allows the enzyme to retain its activity by preserving the active site from any possible denaturation (Nguyen \& Kim, 2017). In this type of process, the enzyme in its crude or purified form is first contacted with the supporting solid for a period, and then the enzyme-carrier complex is recovered and washed to remove the unbound enzyme. However, this technique suffers from easy enzyme desorption mainly caused by the weakness of attraction forces, variations in $\mathrm{pH}$, temperature and ionic strength. Unlike adsorption, covalent attachment is achieved by stable covalent bonds between the functional groups of enzyme molecules and the 
chemically modified support matrix. The functionalized support undergoes activation using a crosslinking agent (glutaraldehyde, carbodiimide, disuccinimidyl suberate, epichlorohydrin, genipin or various bifunctional agents) that ensure reactivity towards protein functional groups. The functional group present on the enzyme molecules should not be essential for the enzymatic activity, which usually involves the binding via the side chains of lysine ( $\varepsilon$-amino group), aspartic acid (carboxylic group), cysteine (thiol group) (Novick \& Rozzell, 2005). Thus, the enzyme leakage rate from the host matrix is considerably reduced. Nevertheless, the complexity of the process, the problems associated with steric hindrance and the risk of protein structure denaturation represent a serious handicap for this technique. Entrapment is also a part of strategies using solid organic or inorganic matrix. It is a method based on the confinement of enzymes within the internal cavities of a gels or fibers by covalent or non-covalent bonds (Singh, 2007). Enzyme caging is carried out under mild conditions following a variety of procedures such as microencapsulation, photopolymerisation, electropolymerization or sol-gel process (Spasojević et al., 2019). The method exhibits almost no effect on the enzymatic structure due to the weak enzyme/matrix interactions. The enzyme is first mixed into a monomer solution, which is subsequently polymerized. One of the advantages of this technique lies in the ability to provide a beneficial microenvironment for the enzyme, depending on the material of the gel and its modification. However, an alteration in the chemical and physical properties of the matrix can affect the kinetic behavior of an enzyme for a giver reaction. The system is also unsuitable for macromolecular substrates involving a slowing rates diffusion. In addition, the enzyme leakage can be substantial when the polymer network has large pores (Sassolas et al., 2012). 
The applied supports for enzyme insolubilization are commonly divided into two main categories: organic and inorganic. The first group includes compounds of naturel and synthetic origin such as cellulose, dextran, chitosan, alginate, polyacrylamide, poly(vinyl alcohol), or even polyamides for certain applications. While inorganic supports are constructed from silica-based and oxide-based materials such as ceramics, titania, alumina, zirconia (Zucca \& Sanjust, 2014). Recently, enzymatic immobilization has seen the use of a new type of material endowed with biocompatible, robust and recoverable properties. Metal-organic frameworks (MOF) emerged as a promising support material with a number of advantages, such as porosity and high surface area, which is desirable for the accommodation of biocatalysts; uniformity of the size and shape of the pores with the possibility of adjusting their size; resistance to metal aggregation and structural degradation, thus offering the possibility to reuse the support (Bilal et al., 2019). Carbonaceous nanomaterials were also considered a potential support carrier for enzymes immobilization notably for their exceptional optical, electrical, chemical and thermal activities (Bilal et al., 2020).

In a completely different approach, cross-linked enzyme aggregates (CLEAs) are one of the rare insolubilization techniques that do not require the use of a support. The development of water-insoluble CLEAs particles involves the combination of precipitation, purification and immobilization into single unit operation. Physical aggregation of enzymes is achieved by addition of salts, water-miscible organic solvents or nonionic polymers without denaturation (Hanefeld et al., 2009; Spasojević et al., 2019). Subsequent cross-linking of the precipitated biocatalysts using a linker molecule such as glutaraldehyde renders them permanently insoluble while maintaining their protein structure, and therefore their catalytic activity (Sellami 
et al., 2021). The quantities of precipitating and crosslinking agents as well as biocatalyst amount must be optimized for each enzyme in order to ensure maximum recovery of the catalytic activity. CLEA technology has the advantage of being easy to implement with low production costs. In addition, the absence of a solid support makes it possible to obtain a mass consisting essentially of proteins with low mechanical stress. Storage stability, recovery and reuse are also advantages attributed to the carrier-free immobilization technique. Despite the several advantages, a lack of enzyme aggregates size control, mass-transfer issues and rigidity can affect CLEAs performances (Sheldon \& van Pelt, 2013).

New strategies have also been developed in recent years, where the advantages of different techniques are combined to overcome the drawbacks of the techniques used individually and obtain a robust biocatalyst with long lasting life (Cui et al., 2016; Cui et al., 2014; Cui \& Jia, 2013). Immobilization methods are illustrated in Fig. 2.

In this section, the various challenges of industrial and environmental applications of peroxidase are described and discussed.

\subsection{Removal of phenolic contaminants}

Enzyme-based processes using peroxidases have shown significant potential for phenols polymerization. These kind of aromatic compounds represents one of the major classes of pollutants. Very often detected in wastewater from diverse industries including plastics, textiles, coal conversion, petroleum refining, paint, pulp and paper (Mohammadi et al., 2015). All studies carried out on the treatment of industrial effluents containing these substances have mentioned the degree of phenols toxicity, and have indicated their impacts on humans and the environment (Dargahi et al., 
2017; Sridhar et al., 2018). Several published works have developed a process combining biology and catalysis to result in a biological catalyst with high selectivity, better tolerance to phenol and its derivatives while overcoming the inhibitory effect encountered by micro-organisms (Karigar \& Rao, 2011). The conversion of phenol by HRP has been widely used in the field of wastewater treatment. Other sources of peroxidases have also been identified and proposed as substitutes for HRP, such as soybean hulls which are an abundant by-product of food industry (Wilberg et al., 2002). Turnips contain peroxidase enzyme and showed an attractive potential for phenol degradation (Azizi et al., 2014). Peroxidases extracted from bitter gourd (BGP) also have a pronounced ability to remove phenols from contaminated wastewater (Ashraf \& Husain, 2011). Peroxidases mediate phenol transformation, which is activated by hydrogen peroxide; phenoxy radicals are generated to finally form a polymeric precipitates (Huang et al., 2002). Alemzadeh and Nejati (2009) employed encapsulated HRP in five successive batch reactions for phenol removal. The experimental study showed that dropping $5.5 \%(\mathrm{w} / \mathrm{v})$ of calcium chloride solution containing a pre-determined enzyme concentration in $1.0 \%(\mathrm{w} / \mathrm{v})$ of sodium alginate gel improved enzyme retention in the matrix. Immobilized HRP displayed a good chemical stability with an important phenol conversion efficiency $(\approx 80 \%$ ) without altering enzyme activity after 4 repeated tests. The results revealed that an [H2O2] / [phenol] $=1$ molar ratio was sufficient to achieve optimum conversion. This value corresponds to the $1: 1$ stoichiometry found for phenols polymerization (Wagner \& Nicell, 2001). However, based on the catalytic cycle of peroxidases, when the enzyme is oxidized by one molecule of hydrogen peroxide, two molecules of phenol are oxidized. Consequently, the stoichiometric ratio between the peroxide consumed and the precipitated phenolic compound is equivalent to a theoretical value of $1: 2$ 
provided that the formed dimer is insoluble. This difference in stoichiometry between the theoretical and measured value was explained by a sequence of reactions by soluble dimers with the enzyme to produce polymers of larger size. In fact, the soluble coupling products can serve as phenolic substrates and undergo further transformation until trimmers, tetramers or larger polymer is formed which is insoluble in water. Thus, the more the size of the polymers increases during the polymerization reaction, the more [H2O2] / [phenol] ratio tends towards unity as a limit (Nicell et al., 1993). Vasileva et al. (2009) demonstrated the degradation of phenol by covalently immobilized HRP on modified ultrafiltration membranes at a flow rate of $1.02 \times 10^{-5}$ $\mathrm{m}^{3} \mathrm{~m}^{-2} \mathrm{~s}^{-1}$. A total removal of phenol was noticed for concentrations ranging from 5 to $40 \mathrm{mg} \mathrm{L}^{-1}$ with $0.5 \mathrm{mmol} \mathrm{L}{ }^{-1}$ of hydrogen peroxide initial concentration. In another work, cross-linked peroxidase isolated from black radish was assessed for phenol and p-cresol polymerization in the presence of $\mathrm{H}_{2} \mathrm{O}_{2}$. The immobilized enzyme exhibited a good storage stability for more than 8 weeks and was characterized by a high tolerance to $\mathrm{pH}$ and temperature variations. The resulted aggregated peroxidase recorded a maximal yield of $98 \%$ for $p$-cresol and $92 \%$ for phenol respectively. The reuse study revealed that immobilized biocatalyst was able to transform phenolic compounds over 4 successive cycles without any treatment or washing operation. However, it should be noted that during the enzymatic transformation of phenol, some polymeric deposits occur on the surface of the immobilized enzymes which implies a decrease in the catalytic performances (Sellami et al., 2021). The main disadvantage of enzymatic bioconversion is that enzymes suffer from inactivation during the reaction. One of the possible pathways causing peroxidases inactivation is their sorption/occlusion by the formed polymers. Nakamoto \& Machida (1992) suggested that the adsorption of the enzymatic molecules by the product resulting 
from phenol polymerization hinders the access of the substrate to the enzyme active site. Yu et al. (1994) identified the polymeric products resulting from phenol conversion and revealed that only $7 \%$ of the formed precipitate mass was dimers ( $p, p^{\prime}$-biphenol, o,o'-biphenol and $p$-phenoxyphenol) while the rest of the phenol molecules were polymerized into oligomers characterized by high hydrophobicity. The authors demonstrated that the three dimers were subject for further oxidation by peroxidase to generate tetramers or trimmers through coupling dimeric radicals or by reaction of dimeric radicals with monophenoxy radicals, respectively. The study concluded that the predominant polymerization bonds in the phenol transformation precipitates expected to be oxygen-para connections or/and para-para ones. Researchers conducted an enzymatic treatment for phenol and p-chlorophenol in a magnetically stabilized fluidized bed reactor. HRP was grafted on activated magnetic poly(glycidylmethacrylate-co-methylmethacrylate) beads using glutaraldehyde. At a flow rate of $20 \mathrm{~mL} \mathrm{~h}^{-1}$, phenol and $\mathrm{p}$-chlorophenol concentrations were reduced by $100 \%$ and $92 \%$ respectively. A considerable inactivation rate of HRP catalytic activity was observed during the oxidation of $p$-chlorophenol in comparison with phenol. The study suggested a possible involvement of released chlorine ions in the inhibition of the biological catalyst during the biodegradation process (Bayramoğlu \& Arica, 2008). The release of chlorine ions was the result of oxidative coupling reaction and takes place when the unpaired electron of a free radical is located at a chlorine substituted aromatic carbon (Park et al., 2000), rather than enzyme activity (Szatkowski et al., 2011). The concentration of released chlorine was found to constitute about 20 to $25 \%$ of the total chlorine initially associated with chlorophenols (Dec \& Bollag, 1990; Tatsumi \& Wada, 1996). However, it is important to note that the position of substituent groups influences on the enzymatic oxidation of 
chlorophenols. Indeed, the activity of peroxidases increases according to the meta < ortho < para positions of the chloride atom (Yamada et al., 2007). Recently, researchers have successfully supported HRP onto modified reduced graphene oxide nanoparticles (RGO·NH $\mathrm{NH}_{2} @ \mathrm{HRP}$ ) by simple physical adsorption. At an optimum $\mathrm{pH}$ equal to 7 , functionalized support-HRP showed better catalytic performance compared to free enzyme. Indeed, an increase in the catalytic constant $k_{\text {cat }}$ and catalytic efficiency $k_{\text {cat }} / K_{\mathrm{m}}$ was observed, reaching values 6 to 7 times higher. After 35 days of storage, free HRP retained more than $60 \%$ of its initial activity while the immobilized HRP retained only $55 \%$ of its initial activity. The decrease of $\mathrm{RGO} \cdot \mathrm{NH}_{2} @ \mathrm{HRP}$ activity was greater because the nanoparticles tend to aggregates, thus causing enzyme entrapment. However, for $2500 \mathrm{mg} \mathrm{L}^{-1}$ initial phenol concentration, the supported horseradish peroxidase conducted a total degradation of the pollutant against $53 \%$ achieved by free HRP after 40 min reaction time (Vineh et al., 2018). Chang et al. (2016) synthesized graphene oxide $/ \mathrm{Fe}_{3} \mathrm{O}_{4}$ nanoparticles for enzyme immobilization and its application in phenol removal from aqueous solution. The resulted carrier was used for the covalent immobilization of HRP by cross-linking with 1-ethyl-3-(3-dimethyaminopropyl)carbodiimide. The insolubilized biocatalyst kept $65 \%$ of its initial activity after binding on support. The obtained removal of phenol and total organic carbon by supported HRP was $95 \%$ and $78 \%$ respectively, within $3 \mathrm{~h}$ reaction period. The interest of this study is the recovery simplicity of the biological catalyst under a magnetic field from aqueous media and its reuse. Azizi et al. (2017) proved the feasibility of a coupled process Fenton/enzymatic polymerization for industrial wastewater remediation. The alginateentrapped turnip peroxidase was used as a complementary treatment to the Fenton oxidation of phenol. The operation achieved $99.3 \%$ of phenol removal with a 
reduction in $\mathrm{COD}$ and $\mathrm{BOD}_{5}$ by $72 \%$ and $66.7 \%$ respectively. For an initial activity of $5 \mathrm{U}$ and a hydrogen peroxide concentration of $10.6 \mathrm{mM}, 165$ min were necessary for a complete enzymatic transformation of the phenol present in the pharmaceutical effluent. SBP was grafted by glutaraldehyde on silanized glass support for continuous conversion of phenol and 4-chlorophenol in stirred tank reactors. The use of sequential treatment by an equal distribution amount of enzyme between both tanks improved phenols removal efficiency. The findings of the work have demonstrated that the first tank acts as a filter for the second one, which implies a decrease in the risk of enzyme deactivation (Gómez et al., 2012).

\subsection{Biodegradation of synthetic dyes}

The colored organic compounds are extensively used for textile dyeing, color photography, paper printing and as an additive in petroleum products. However, these complex aromatic molecular structures participate in the deterioration of aquatic surfaces in terms of water quality and aesthetics (Anjaneyulu et al., 2005). In the Asian region, textile industry represents a significant portion of water pollution, especially in china (10\%) and India (35\%) (Ito et al., 2016). In Bangladesh (2016) nearly 217 million $\mathrm{m}^{3}$ of wastewater loaded with various pollutants were generated by the textile industry (Hossain et al., 2018). Synthetic dyes are toxic substances, recalcitrant and constitutes a serious threat to public health. Many effective methods have been developed and tested for dye removal, essentially based on a physical or chemical treatment processes. However, some techniques suffer some economic disadvantages in the form of high cost realization, a significant energy consumption; technical limitations including restricted applicability and production of hazardous byproducts. Therefore, finding alternative technologies to conventional methods has become a necessity. Enzymatic treatment is presented as cost-effective and eco- 
friendlier method with high potential on an industrial scale. Peroxidases are part of this enzymes category, which can remove dyes from aqueous solutions and reduce their toxicity. Bilal et al. (2018b) used entrapped HRP on a polyacrylamide gel for the treatment of Methyl Orange dye. Immobilized peroxidase achieved more than $90 \%$ of dye decolorization in a packed bed bioreactor. Phytotoxicity tests based on Triticum aestivum and Phaseoulus mungo germination showed that insolubilized biocatalysttreated azo dye product was less toxic than the parent dye. Recently, Sandal-fix Red C4BLN (S.F. Red), Sandal-fix Black CKF (S.F. Black), and Sandal-fix Turq blue GWWF (S.F. Turq blue) removal capability of cross-linked enzyme aggregates Lignin peroxidase (LiP-CLEAs) was compared with those of native LiP. After cross-linking step, the biodegradation efficiency was increased by $55.69 \%, 22.11 \%$ and $54.36 \%$ for S.F. Black, S.F. Turq blue and S.F. Red, respectively. The LiP-CLEAs retained more than $62 \%$ of their initial activity after 3 repeated cycles. A notable decrease in enzymatic activity was observed after 7 consecutive runs (6h per cycle), displaying a value of $21.8 \%, 32.6 \%$ and $34.7 \%$ for S.F. Red, S.F. Black, and S.F. Turq blue decolorization (Parveen et al., 2020). In a further study, Bilal et al. (2016) evaluated mutagenicity and cytotoxicity of remediated textile effluent by soluble and entrapped $\mathrm{MnP}$. Under optimum $\mathrm{pH}(5.0)$ and temperature $\left(40^{\circ} \mathrm{C}\right)$ conditions, the immobilized $\mathrm{MnP}$ was able to accomplish $87.4 \%$ of effluent decolorization in the presence of $\mathrm{H}_{2} \mathrm{O}_{2}$ (1 mmol L-1) and $1 \mathrm{mmol} \mathrm{L}^{-1}$ of 1 -hydroxybenzotriazole (HOBT) used as mediator redox during $5 \mathrm{~h}$ of reaction time. The investigators also demonstrated the reliability of bioassays evaluation methods to validate contaminant detoxification efficiency, presenting them as an alternative to conventional analytical and chemical methods used for toxicity evaluation. After enzymatic treatment, pollutant toxicity and mutagenicity were considerably reduced. Ali et al. (2013) reported a complete 
degradation of Crystal Ponceau 6R (CP6R) by commercial soybean peroxidase. Results showed that $\mathrm{SBP} / \mathrm{HOBT} / \mathrm{H}_{2} \mathrm{O}_{2}$ system achieved $64.5 \%$ of dye mineralization. Based on intermediate products identification, the analysis indicated that both symmetric and asymmetric bond cleavage were involved in CP6R enzymatic treatment. Fig. 3 illustrates a hypothetical reaction/breakdown pathways of CP6R by commercial soybean peroxidase. Courgette peroxidase (CP) extract was partially purified and subjected to immobilization step in entrapped form. Free-CP (FCP) and insolubilized-CP (ICP) were used in a laboratory-scale for Direct Yellow decolorization. It has been shown that both forms were able to oxidize the target molecule under optimal conditions, by obtaining $87 \%$ and $75 \%$ of decolorization yield for FCP and ICP, respectively. The catalytic capacity of ICP remained relatively constant after 3 repeated batches. An analysis of the precipitate by Fourier transform infrared (FT-IR) spectroscopy was carried out where the authors noted the disappearance of parent dye absorption peak and the appearance of a new band at $1649 \mathrm{~cm}^{-1}$ which could correspond to the formation of aromatic compounds like aromatic amines (Boucherit et al., 2013). Hailei et al. (2009) hypothesized that the azo bonds $(-\mathrm{N}=\mathrm{N}-)$ of the characteristic conjugated chromophores in the azo dye molecule were broken.

A hybrid system combining enzymatic catalysis and electrogeneration of $\mathrm{H}_{2} \mathrm{O}_{2}$ was developed for dye-based textile effluent treatment. A two-compartment packed-bed flow reactor operating at a flow rate of $1 \mathrm{~mL} \mathrm{~min}^{-1}$ at $-0.5 \mathrm{~V}$ was used to evaluate HRP-immobilized graphite felt capacity for dye degradation. The electroenzymatic method has successfully decreased Orange II concentration by $74 \%$, which includes azo bond breakage and formation of by-products consisting of an aromatic amine, sulfanilic acid, and other intermediate products (Kim et al., 2005). In a $50 \mathrm{~mL}$ beaker 
filled with HRP covalently attached to the acrylate groups of modified, polysulfone materials were employed for anthraquinone and diazo dyes degradation at $\mathrm{pH} 5.0$ for 1h. The supported enzyme displays a good retention of its catalytic activity for nearly 46 days, while the native enzyme completely loses its catalytic activity after only 16 days. The experiments were concluded by an effective removal of $70 \%$ for both Acid Black 1 and Reactive Blue 19 (RB-19) after 3 reuse (Celebi et al., 2013). Kalsoom et al. (2013) reported that peroxidase induce the diazo dye destructuring via symmetrical azo cleavage and radical-initiated ring opening of metabolites. It was also mentioned that no formation of polymers was observed due to the complexity of dye structure. The balance is shifted in favor of smaller (less aromatic) intermediates that may eventually be mineralized to $\mathrm{CO}_{2}$ and ammonium ions, rather than generating high molecular weight precipitate. On the other hand, the degradation of $\mathrm{RB}-19$ is initiated by the cleavage of the $\mathrm{C}-\mathrm{N}$ bond which leads to the formation of two by-products $(\mathrm{m} / \mathrm{z} 322)$ and $(\mathrm{m} / \mathrm{z} 265)$. Then, the resulting intermediates will be subjected to several transformation processes including cleavage of quinone ring, oxidation of the hydroxyl group and reduction of the $-\mathrm{COOH}$ group. Adipic acid $(\mathrm{m} / \mathrm{z}$ 148), glutaric acid ( $m / z 132)$ and 2-hydroxypropanoic acid $(m / z 90)$ were identified as the final fractions of RB-19 decomposition (Bilal, Rasheed, et al., 2019).

\subsection{Biotransformation of pharmaceutically active compounds (PhACs) and pesticide products}

Improving life quality and increasing average longevity are closely linked to progress in health care but also the results of better access of individuals to medication. In 2015, nearly 3420 billion doses of pharmaceutical were used worldwide (Mezzelani et al., 2018). China considered as the world's largest producer and consumer of pharmaceutical products, uses more than 25000 tons of antibiotics per year (Xie et 
al., 2019). This remarkable advance is not without consequences for natural ecosystems. Indeed, these compounds considered today as emerging contaminants (ECs) are detected in the various environmental matrices and wastewater treatment plants (WWTPs). The aqueous environment is continuously reached by these emerging trace organic chemicals (ng $\mathrm{L}^{-1}$ to $\mu \mathrm{g} \mathrm{L}^{-1}$ ) from different sources such as drain water, human excretion (sewage), landfill leachate, wrongful disposal, or from industries (Archer et al., 2017). Due to the preoccupying ecotoxicological potential of PhACs, the relevance biological approach has already been proven through the strategies implemented for the reduction of these contaminants in the environment (Tiwari et al., 2017). Enzymatic catalysis seems to be the perfect candidate to participate in this transition to green processes, especially for its lower carbon footprint than conventional treatment methods. A wide range of active molecules from pharmaceutical industries has been degraded by the peroxidase enzymes due to their substrate specificity. For example, Ai et al. (2017) described the immobilization of HRP on silica-coated aminated magnetic nanoparticles $\left(\mathrm{HRP} / \mathrm{NH}_{2}-\right.$ $\left.\mathrm{Fe}_{3} \mathrm{O}_{4} @ \mathrm{SiO}_{2}\right)$ via a crosslinking method. The results indicated that the stability of the immobilized enzyme against harsh conditions was improved. After immobilization step, the free and supported enzymes (IM-HRP) were applied for the estrogens (E2) removal under optimal conditions. IM-HRP reduced initial estrogens concentration (1000 $\mathrm{g} \mathrm{L} \mathrm{L}^{-1}$ ) by $80.85 \%$ at $\mathrm{pH} 7.0$ and $24 \mathrm{mg} \mathrm{L}^{-1} \mathrm{H}_{2} \mathrm{O}_{2}$. It is important to stress that the native enzyme achieved a better degradation efficiency with a maximum of 89.5\% estrogens disappearance. The researchers group also demonstrated the involvement of the $\cdot \mathrm{OH}$ and $\cdot \mathrm{O}_{2}^{-}$radicals in E2 degradation with dominant oxidant tendency for $\mathrm{O}_{2}{ }^{-}$radicals. Metabolites identification analysis confirmed the presence of two intermediates ( $\mathrm{m} / \mathrm{z} 178.98$ and 288$)$ after E2 conversion. More than $45 \%$ 
estrogens amount from aqueous media was removed by IM-HRP during 7 reaction cycles. In recent published paper, VP was assembled with laccase and GOD enzymes in carrier-free immobilization form by successive aggregations, and using chitosan with 1-ethyl-3-(3-dimethyaminopropyl)carbodiimide hydrochloride as crosslinker agent. Then, the combined CLEAs (combi-CLEAs) were experimented for PhACs removal in synthetic solutions and municipal wastewaters. The designed versatile biocatalyst resulted in a decrease of catalytic activity, where laccase saved only $27.7 \%, 38.9 \%$ for VP and $36.4 \%$ for GOD, whereas thermal and $\mathrm{pH}$ stability, conversely, were upgraded. The enzymatic biotransformation of acetaminophen, naproxen, mefenamic acid, diclofenac and indometacin present in mixed solution achieved more than $80 \%$ of degradation yield. The results of enzymatic-based treatment of real wastewater provide insight of combi-CLEAs oxidative potential in the cascade conversion of various molecules (Touahar et al., 2014). A comparative study between enzymatic transformation and chemical $\left(\mathrm{UV}+\mathrm{H}_{2} \mathrm{O}_{2}\right)$ destruction of sulfamethoxazole (SMX) was conducted by Al-Maqdi et al. (2018). The first tests related to the use of an $\mathrm{SBP} / \mathrm{H}_{2} \mathrm{O}_{2}$ system revealed the need to include a redox mediator (HOBT) to achieve $80 \%$ of SMX degradation within 10 min of the started reaction. From this study, it was found that the remediation mechanisms followed different pathways during enzymatic biocatalysis or in the case of chemical oxidation. Indeed, in a system $\left(\mathrm{UV}+\mathrm{H}_{2} \mathrm{O}_{2}\right)$ a cleavage occurs at $\mathrm{N}-\mathrm{O}$ bond which leads to the formation of hydroxylated intermediates $(\mathrm{m} / \mathrm{z} 254$ and 270$)$; on the other hand, $\left(\mathrm{SBP} / \mathrm{H}_{2} \mathrm{O}_{2} / \mathrm{HOBT}\right)$ system generated smaller products $(\mathrm{m} / \mathrm{z} 99$ and 120). The degradation pathways of sufamethoxazole by soybean peroxidase is illustrated in Fig. 4 In a recent investigation, Pylypchuk et al. (2020) conducted a physical adsorption of HRP and LiP onto silica-coated magnetite nanocomposites to remove 
an array of different pharmaceuticals. The immobilized green catalysts exhibited a high resistance to elevated temperature $\left(55^{\circ} \mathrm{C}\right)$ and denaturing environments, such as acidic medium. In addition, the silica shell formed around HRP and LiP loaded onto the spherical particles prevents enzyme leakage and allows them a long-term and durable stability over 20 successive cycles for 20 days ( $24 \mathrm{~h}$ per cycle). The immobilized HRP and LiP performed a complete removal of diclofenac and carbamazepine at $\mathrm{pH} 3.0 \quad\left(55^{\circ} \mathrm{C}\right)$ after $72 \mathrm{~h}$ of enzymatic treatment. The characterization of by-products from drug decomposition suggest a hydroxylation of the compound by peroxidase enzymes. A presence of two metabolites was revealed according to the referenced studies, namely 4'-hydroxy-diclofenac and 5-hydroxydiclofenac. It has been also indicated that $5-10 \%$ of the treated recalcitrant pollutant was converted into diclofenac-2,5-iminoquinone, while most of the molecule was probably eliminated by other pathways. The LiP oxidative properties involve the formation of radical cation throught one electron oxidation, leading to side-chain cleavage, demethylation, intramolecular addition and rearrangements (Wong, 2009). It generates and forms a tryptophanyl radical on the surface of the enzyme through electron transferring to the heme molecule. Tryptophan variability is a factor that can modulate the enzyme activity, stability and substrate specificity (Falade et al., 2017). In their study, Wen et al. (2010) appraised the degradation capability of manganese peroxidase produced from Phanerochaete chrysosporium to reduce the concentration of two pharmaceutical compounds present in the reaction medium. Decomposition profile indicated a degradation efficacy of $84.3 \%$ and $72.5 \%$ for oxytetracycline (OTC) and tetracycline (TC), respectively, within $4 \mathrm{~h}$ using $40 \mathrm{U} \mathrm{L}^{-1}$ of initial enzyme activity. It was noticed that applying $\mathrm{MnP} / \mathrm{co}$-reactant $\left(\mathrm{H}_{2} \mathrm{O}_{2}\right)$ system improved TC conversion. It was also observed that the optimal rate of OTC and TC 
elimination was obtained with almost two equivalents of $\mathrm{H}_{2} \mathrm{O}_{2}$ to antibiotic. While in the case of estrogenic compounds, Zdarta et al. (2021) reported that the stoichiometry of the $\mathrm{H}_{2} \mathrm{O}_{2}$ / estrogen ratio was 0.45 which correspond to the theoretical molar stoichiometry of peroxide-to-substrate described by Auriol et al. (2007).

Pesticides are defined as substances that fight against organisms considered to be harmful. They bring together the biocidal actions of insecticides and herbicides to ensure the conservation of plant products. However, these products are often at the origin of surface water contamination by runoff and by ignorance of parameters, which could have an influence, such as soils permeability and the location of underground drainage systems (Leu et al., 2004). These chemicals are also known for their adverse effects on human health corresponding to birth defects, neurologic deficits, cancer and memory disorders (McCauley et al., 2006). Peroxidases show an interesting potential for reducing pesticides toxicity in soils (Pizzul et al., 2009). For example, Mougin et al. (1994) reported that white rot fungus Phanerochaete chrysosporium decomposed atrazine herbicide into deethylatrazine and hydroxyatrazine, which were less toxic than the parent molecule. From the peroxidases activity profiles, LiP and MnP were involved in the degradation process of atrazine. The herbicide triazine (hexahydro-1,3,5-trinitro-1,3,5-triazine) present in soil sample was incubated with Rhodococcus sp. strain DN22 for its biological transformation. A ring cleavage metabolite (4-nitro-2,4-diazabutanal) was produced and subsequently used as nutriment by Phanerochaete chrysosporium, which led to a complete mineralization of the compound with the liberation of nitrous oxide. It has been proven that $\mathrm{MnP}$ was implicated in triazine removal (Fournier et al., 2004). In a further study, chloroperoxydase (CPO) from Caldariomyces fumago catalyzed the 
biotransformation of pesticides pentachlorophenol (PCP) and 2,3,5,-6tetrachlorophenol (TCP) leading to their polymerization, and thus reduce their toxicity. The CPO conversion of PCP led to the formation of an insoluble polymer, dimer and tetrachlorobenzoquinone (TCBQ), while a trimer was identified after CPO transformation of TCP (Longoria et al., 2008). Samokyszyn et al. (1995) explained that the mechanism governing PCP conversion to TCQB by peroxidases included the formation of oxygen-based radical followed by radical delocalization and $p$-chlorine release. Rüttimann-Johnson \& Lamar (1996) suggested that the TCBQ produced by peroxidase enzymes could easily polymerize into higher molecular-weight material. However, another was has also been proposed to describe the formation of TCBQ. The dimers are first formed by a coupling reaction of phenoxyl radicals, then in a second step they are decomposed to form the quinone molecule (Kazunga et al., 1999). This last route was supported by the results obtained by Longoria et al. (2008) where only $2.5 \%$ of $\mathrm{PCP}$ was converted into TCBQ.

\subsection{Bio-oxidation of polycyclic aromatic hydrocarbons (PAHs) and polychlorinated biphenyls (PCBs) molecules}

PAHs are molecules containing carbon and hydrogen atoms, whose structures includes at least two condensed aromatic rings. These organic contaminants are characterized by their semi-volatility, low water solubility and easily adsorbed in soils and sediments. Several studies reported enzymatic transformation of PAHs into simple chemical structures using fungal ligninolytic enzymes (Haritash \& Kaushik, 2009). In vitro degradation of anthracene by $\mathrm{MnP}$ has been studied in the presence of cofactors and mediators $\left(\mathrm{Mn}^{2+}, \mathrm{H}_{2} \mathrm{O}_{2}\right.$ and organic acids) and other influencing elements (oxygen, temperature and light source). To allow better contact between MnP-enzyme and PAH-substrate, mixture of water/miscible organic solvent 
containing $36 \%$ acetone (v/v) was used, which upgraded anthracene solubility by 140 times. The oxidation of anthracene was quite effective, $100 \%$ anthracene was removed in $6 \mathrm{~h}$ by $\mathrm{MnP}$ (Eibes et al., 2005). The same group carried out enzymatic degradation of recalcitrant polyaromatic compounds including dibenzothiophene, pyrene and anthracene, using $\mathrm{MnP}$ as reaction catalyst and acetone as co-solvent. The results showed that anthracene was converted to 9,10-anthraquinone which then underwent further oxidation to form phthalic acid, and had highest degradation rate followed by dibenzothiophene oxidation which resulted in a ring cleavage product 4methoxybenzoic acid and hydroxylation of pyrene transformed to 1-hydroxypyrene intermediate. The authors quantified the concentration of the formed anthraquinone which reached $12 \mu \mathrm{M}$. This value represented more than $50 \%$ of the degraded anthracene, making it the main product of the reaction (Eibes et al., 2006). The enzymatic degradation of anthracene goes through several stages. First, the polycyclic aromatic ring undergoes one-electron oxidation to give a cationic radical. This species can then accept water to yield a hydroxylated aromatic free radical that gives 9-hydroxyanthracene intermediate after oxidation. A similar series of steps would yield the hydroquinone. Finally, the anthraquinone is obtained by a twoelectron oxidation of hydroquinone (Kraus et al., 1999) .Torres et al. (1997) experimented the degradation of $18 \mathrm{PAH}$ molecules using lingnin peroxidase, cythochrome $\mathrm{c}$ and haemoglobin. It was observed that aromatic compounds characterized by an ionization potential less than $8 \mathrm{eV}$ were converted by LiP. In the presence of $\mathrm{H}_{2} \mathrm{O}_{2}$, anthracene was oxidized to form anthraquinone products; 2methylanthracene decomposition generated 2-methylanthraquinone compound; pyrene and benzo[a]pyrene conversion resulted in pyrenedione and benzo[a]pyrenedione ending products; and the mass spectra of metabolites from 
acenaphthenone transformation corresponded to 1-acenaphthenona and 1acenaphthenol. Eibes et al. (2010) investigated anthracene degradation in an enzymatic two-phase partitioning bioreactor (TPPB) using VP produced from white rot fungus Bjerkandera adusta. For a better bioavailability of the target pollutant, an immiscible organic phase (silicone oil) was used to achieve complete solubilization of the polycyclic aromatic compound. Then, effects of various factors were studied, including agitation rate, solvent viscosity and surfactant concentrations. Under optimal conditions, $88 \%$ of anthracene consumption was obtained after $38 \mathrm{~h}$. It was noticed that using a hydrophobic solvent was more benefic for the enzyme structure which can be explained by the hydrophobicity of the medium, while a stripping phenomenon occurs in the case of hydrophilic solvents which tend to bind to water layer surrounding the proteins and thus leading to their denaturation.

Polychlorinated biphenyls molecules are industrially synthesized and chemically close to dioxins. Depending on their chlorine content, they can be liquid or resinous and are insoluble in water. The chemical stability of PCBs leads to their persistence in the environment and their concentration in the food chain. PCBs are considered toxic, ecotoxic and reprotoxic (Borja et al., 2005). There are some potential applications of enzymes that have been identified PCBs degradation. For example, Colosi et al. (2007) developed an oxidative coupling processes for indirect removal of polychlorinated biphenyl contaminant. In fact, the introduction of a co-reactant more reactive than the target compound with respect to the catalyst leads to the formation of nonspecific free radicals, which are involved in the coupling reactions between substrates to transform them into larger molecular aggregates. This hypothesis was demonstrated by incorporating 2,2'-dichlorobiphenyl (PCB-4) covalently with the aggregation of natural organic matter (NOM), after catalysis of Suwannee River fulvic 
acid used as co-substrate by HRP. For a better understanding of the phenomenon, phenol and 4-methoxyphenol were used as alternative co-substrates for PCB-4 removal. The results indicated that the elimination of the compound was related to molecular characteristics of the native co-substrate and its corresponding phenoxyradical stability. Köller et al. (2000) demonstrated the ability of peroxidase enzyme to metabolize PCB substrates. HRP was used to catalyze oxidation of 2,5dichlorobiphenyl (PCB 9) and 2,2',5,5'-tetrachlorobiphenyl with hydrogen peroxide as co-substrate. After $220 \mathrm{~min}$ of reaction time, the enzymatic catalyst reduced the amount of PCB 9 and PCB 52 by $90 \%$ and 55\%, respectively. The metabolites formed were principally dechlorinated hydroxybiphenyls, benzoic acids, nonsubstituted 1,1'-biphenyl, some higher chlorinated biphenyl isomers were identified, following the first dechlorination step. Based on the intermediates generated during the conversion of PCBs by peroxidase, the authors have suggested two main steps, dechlorination with release of chloride ions and hydroxylation. Indeed, after the dechlorination of PCBs or hydroxylated PCBs, the dechlorinated hydroxybiphenyls and 1,1'-biphenyl undergo further hydroxylations. As for the formation of the aromatic carboxylic acid, this is the result of subsequent reaction, in particular the cleavage of the cyclic system. Additional results also revealed the appearance of side reactions, which remain very weak, such as dimerization of phenyl radicals, and the reaction of phenyl radicals with PCBs. In parallel, an experiment was carried out using white rot fungus Trametes multicolor for PCB 9 removal which achieved $80 \%$ of degradation efficiency after 4 weeks. Analysis of the intermediates revealed the presence of dichlorobenzenes, chlorophenols and alkylated benzenes. In a further study, researchers investigated biotransformation of various PCB molecules using HRP and cytochrome c enzymes. It was observed that HRP obtained a better transformation 
rates for di-, tetra- and hexa-chlorinated biphenyls as compared to tri- and pentachlorinated biphenyls. The results of biodegradation displayed an average percent removal ranging from 60 to $80 \%$, depending on the congener (A. Singh et al., 2000).

\subsection{Treatment of odorant substances and hydrophobic volatile organic compounds (VOCs)}

Olfactory pollution is generally due to a multitude of compounds generated from agricultural operations and food industry discharged into the atmosphere. Among the molecules detected in the polluted air, volatile fatty acids, indoles and phenols, ammonia and volatile amines, hydrogen sulfide and mercaptans (Rappert \& Müller, 2005). In agricultural facilities, a high concentration of ammonia and nitrogen compounds present in stored manure, results in health problems for both animals and human workers (Whitehead \& Cotta, 2004). Some potential applications of enzymatic treatment for manures deodorization were described in earlier reports (Govere et al., 2005, 2007). Ye et al. (2009) investigated a biocatalytic process using HRP with co-reactants $\left(\mathrm{H}_{2} \mathrm{O}_{2}\right.$ or $\left.\mathrm{CaO}_{2}\right)$ for the reduction of swine manure odor intensity. Bioremediation tests were carried out on seven malodorous compounds, including isobutyric acid, isocaproic acid, isovaleric acid, phenol, p-cresol, indole and skatole. Depending on peroxide type or concentration used for deodorization experiments, the odor intensity in a confined build was abated by $54-84 \%$ in all operations. It was observed that $100 \%$ of $p$-cresol was removed, $32-54 \%$ of bioremediation efficiency was accomplished for indolic compounds and degradation of $28-41 \%$ was achieved for volatile fatty acid pollutants. The treatment effect can last up to 48h. A commercial SBP enzyme in combination with $\mathrm{H}_{2} \mathrm{O}_{2}$ or $\mathrm{CaO}_{2}$ was applied for reducing odorous compounds emissions from standard phenolic solutions and swine manure. It was observed that the most relevant odorant product in a fresh 
manure was $p$-cresol, which displayed an odor activity value (OAV) varying from 68 to $81 \%$. During $24 \mathrm{~h}$ of bio-based treatment, $62 \%$ and $98 \%$ of the emitted p-cresol was removed using $\mathrm{H}_{2} \mathrm{O}_{2}$ and $\mathrm{CaO}_{2}$, respectively. The researchers indicated that $\mathrm{SBP} / \mathrm{CaO}_{2}$ system led to better results by reducing the flow of the odorous compound (p-cresol) by $98 \%$ in $24 \mathrm{~h}$ and by $92 \%$ after $48 \mathrm{~h}$ of treatment, with corresponding decreases in summed OAVs of $94 \%$ and $68 \%$ (Parker et al., 2012).

In the case of hydrophobic VOCs, an aqueous phase treatment operation may be complicated due to their low solubility. Some authors suggested the introduction of non-aqueous phase in a Two-Phase Partitioning Bioreactor (TPPB) to improve the transfer of the hydrophobic VOC from gaseous phase to the liquid phase (aqueous + organic solvent), followed by a degradation using microorganisms (Béchohra et al., 2015; Lhuissier et al., 2018). However, the need to rule out problems linked to the separation of the two liquid phases at the end of the treatment, bioavailability of VOCs for microbiological species and organic phase regeneration (Muñoz et al., 2007), have led to present an alternative solution that is simpler in its implementation involving a single organic phase and a biocatalyst. Tandjaoui et al. (2016) developed an innovative technique for air waste treatment combining VOC absorption in a neat organic phase followed by its enzymatic transformation. The catalytic activity of the enzyme being altered by its presence in a non-aqueous medium must undergo certain modifications to withstand the denaturing effect of the organic solvent (silicon oil); consequently, Brassica rapa peroxidase was immobilized using cross-liking method (BRP-CLEAs) (Tandjaoui et al., 2015) which resulted in regenerable and insoluble enzyme for 2-chlorophenol (2-CP) removal in organic solvent. The study showed that the absorption capacity of 2-CP was better in silicon oil than in water medium by displaying an air-oil partition coefficient value of $0.136 \mathrm{~Pa} \mathrm{~m}^{3} \mathrm{~mol}^{-1}$, which 
was five times lower than air-water partition coefficient. Bioremediation experiments revealed that in the presence of $6 \mathrm{mM}$ hydrogen peroxide amount, $69 \%$ of $2-\mathrm{CP}$ initial concentration (80 $\mathrm{mg} \mathrm{L}^{-1}$ ) was converted using $2.66 \mathrm{U} \mathrm{mL}^{-1}$ of BRP-CLEAs. After 3 batches (100 min per cycle), 59\% of initial removal efficiency was retained The same group demonstrated the degradation of a hydrophobic VOC (toluene) by an integrated process coupling absorption and enzymatic catalysis. Silicon oil (PDMS 47V20) was used as VOC reservoir, which exhibited a high affinity for toluene. Mean value for toluene partition between gas phase and organic solvent was determined as $2.08 \mathrm{~Pa} \mathrm{~m}^{3} \mathrm{~mol}^{-1}$, which was approximately 333 times lower than the one obtained by water. The toluene biotransformation was optimized by adopting a statistical method based on response surface methodology (RSM). BRP-CLEAs with initial enzyme activity of $8.56 \mathrm{U} \mathrm{mL}^{-1}$ was applied for toluene removal. From biodegradation tests carried out over a period of $4 \mathrm{~h}$, it was observed that $60 \%$ of toluene at $366.3 \mathrm{mg}$ $\mathrm{L}^{-1}$ initial concentration was converted, in the presence of $\mathrm{H}_{2} \mathrm{O}_{2}$ as co-substrate $(0.175 \mathrm{M})$ (Tandjaoui et al., 2020). The oxidation of aromatic compounds begins with the hydroxylation of the $\mathrm{C}-\mathrm{H}$ aliphatic bond. The oxygen molecule involved in this transformation comes from hydrogen peroxide (Ullrich \& Hofrichter, 2007). Zaks \& Dodds (1995) have shown that chloroperoxidase was able to catalyze the oxidation of toluene and benzene to the corresponding benzaldehyde. The mechanism of benzylic oxidation of toluene has been proposed by (Kinne et al., 2010). The transformation was catalyzed by the extracellular peroxidase of Agrocybe aegerita. Oxidation of toluene leads to the formation of benzaldehyde and benzoic alcohol, which undergo further oxidation to give benzoic acid as the end product of the transformation cycle.

\section{Peroxidases in the detection of target compounds}


Biosensors are analytical instruments engineered for the detection and quantification of analytes constituting the center of interest for a chemical or toxicological analysis procedure. The immobilized bioelement recognize the target substance in a complex medium and the biological reaction is converted by transducer into a measurable electrical signal, which correlates with the concentration of the target molecule. According to their particular application, biosensors are also employed in medical diagnostics, phathogen and toxin detection in water and food, and environmental monitoring (Leung et al., 2007). Due to their high selectivity and sensitivity, low cost, adaptable design and fast response time, enzymatic biosensors are more beneficial and profitable compared to other analytical techniques. In recent years, enzyme biosensors-mediated electrochemical methods have been developed using various electrochemical signal transducers, where enzyme is preserved by immobilization. Peroxidases showed an immense potential as bioanalytical tool and were extensively used in the development of biosensors (Ruzgas et al., 1996). Due to its involvement in the progression of Alzheimer's disease, Parkinson's disease and other neurodegenerative disorders, the rapid and reliable analysis of hydrogen peroxide has become a very attractive line of research in various fields (Chen et al., 2012). For the first time, HRP-based biosensor for hydrogen peroxide and glucose detection has been developed using tin oxide grafted glass. The bioreceptor was covalently immobilized to the silanized electrode surface, which was able to achieve a detection limit of $\mathrm{H}_{2} \mathrm{O}_{2}$ of $10^{-8} \mathrm{M}$. Then, a bi-enzymatic system using HRP/GOD was employed in the determination of glucose concentration, the sensor showed high performance and good sensitivity (Tatsuma et al., 1989). Recently, Rahemi et al. (2016) coated Au electrodes by a composite mixture containing $\mathrm{TiO}_{2}$-entrapped $\mathrm{HRP}(50 \%), 45 \%$ of graphite and $5 \%$ nafion $^{\circledR}$. The obtained enzyme electrode exhibited a hydrogen 
peroxide detection limit of $1 \mu \mathrm{M}$ with an average sensitivity of $1 \mathrm{~A} \mathrm{M}^{-1} \mathrm{~cm}^{-2}$. The researchers observed a significant increase of $\mathrm{H}_{2} \mathrm{O}_{2}$ reduction when mesoporous $\mathrm{TiO}_{2}$ was introduced as platform for $\mathrm{HRP}$ in comparison with non-porous $\mathrm{TiO}_{2}$. At the same time, biosensors also have an ability to transmit a number of information that can give an indication about cytotoxicity and genotoxicity of the examined or monitored chemical compound. Selective inhibition of the enzymes by the target contaminant followed by a decrease in the catalytic activity of the immobilized biological catalyst allows analyte quantification by the enzymatic biosensors. The vast majority of peroxidase-based electrochemical biosensors have been used for $\mathrm{H}_{2} \mathrm{O}_{2}$ determination, there are also some applications carried out on the detection of phenolic compounds by immobilized peroxidases on electrodes. A biosensor for rapid detection and determination of phenolic products was developed by adsorbing and cross-linking HRP on a silica-titanium material used for the construction of carbon paste electrode. The low conductivity of silica gels resulted in the suppression of the direct reduction of $\mathrm{H}_{2} \mathrm{O}_{2}$ by the enzyme, which led to an increased detection sensitivity of phenol, catechol, hydroquinone, resorcinol, vanillin and 4-chloro3methyl phenol by HRP-biosensor (Rosatto et al., 1999). Dai et al. (2005) found that when a co-immobilization of tyrosinase and HRP was applied to a mesoporous silica coated electrode, the biosensor sensitivity for phenolic substrates was significantly increased when compared to mono-enzymatic systems, without use of any mediator. The sensitivities of tyrosinase-HRP-biosensor for $\mathrm{p}$-cresol, phenol and catechol were 13, 14 and $45 \mu \mathrm{A} \mu \mathrm{M}^{-1} \mathrm{~cm}^{-2}$, respectively.

\section{The possible role of peroxidases in the transition from fossil fuels to biofuels}


Biofuels or agrofuels are fuels produced from non-fossil organic materials, derived from biomass and which complements or substitutes fossil fuels. The two most common types of biofuel are biodiesel and bioethanol, which are produced from sugars or starch, and lignocellulosic materials with a neutral carbon balance previously fixed by plants during photosynthesis. Lignin is one of the major components of the plant cell wall that is difficult to degrade. Lignin and plant polysaccharides have complex and organized structures that allow them to resist enzymatic attacks. For an improved saccharification, lignin must be physically removed from plant tissues so that the resulting biomass becomes more sensitive to biological conversion (Weng et al., 2008). Several strategies for depolymerizing lignin in lignocellulosic materials have been developed including physical and chemical procedures. However, current delignification approaches have certain economic drawbacks linked to equipment cost and energy consumption; as a result, a massive production of cellulosic biofuel is unfeasible (Hamelinck et al., 2005). Enzymatically metabolizing lignin seems to be a practical and encouraging alternative displaying significant benefits such as, a considerable reduction in energy intake while keeping the same conversion efficiency, an absence of chemicals involved in the chemical treatment process (Sun \& Cheng, 2002). Often, efficient enzymatic degradation of insoluble polysaccharides requires a strong interaction between the enzymes and their substrates. Some strains of fungi produce peroxidases and polyphenol oxidases, which are known to be involved in lignin biodegradation. These enzymes act in a non-specific way, through the generation of unstable free radicals. These renewable biocatalyst include 4 major groups which primarily affect lignin structure namely, lignin peroxidases, manganese peroxidases, versatile peroxidases and laccases (Furukawa et al., 2014; Garlapati et al., 2020). 
Ligninolytic enzymes produced by the white-rot fungi were adopted by several researchers for lignin conversion in different lignocellulosic biomasses. Kong et al. (2017) reported the use of a novel strain fungus (Physisporinus vitreus) for enzymatic recalcitrance reduction of corn stover by relying on its ligninolytic enzymes including VP for efficient bio-delignification. It was observed that saccharification of corn stover achieved a maximum glucose yield of $349.1 \mathrm{mg} / \mathrm{g}$ and $91.5 \%$ of cellulose conversion ratio was accomplished, after 28 days of pretreatment. The fungal pretreatment generated a significant reduction of lignin contents by $54 \%$. The purified VP exhibited a high potential redox of $1.131 \mathrm{eV}$ with oxidative activity on phenolic and nonphenolic monomeric lignin compounds and break different linkages in lignin structure, which make it a suitable biocatalyst for lignin removal in biorefinery processes. Asgher et al. (2013) proposed an ecofriendly approach for bio-ethanol production after delignification of sugarcane bagasse biomass, using ligninolytic enzymes (LiP, MnP, and laccase) extracted from Pleurotus ostreatus. The crude extract produced under pre-optimized solid state fermentation medium managed to eliminate up to $33.55 \%$ of lignin when the reaction was carried out at $35{ }^{\circ} \mathrm{C}$ for $48 \mathrm{~h}$. Recently, researchers have adopted a method that includes waste management and reducing energy consumption. During this study, it was discussed to use old newspaper as a source of lignocellulosic material for bioethanol production. Pre-treatment of the newspaper waste was carried out by a chemical technique (alkali treatment) and enzymatic delignification (ligninolytic). The highest lignin removal of $42.2 \%$ was recorded after $24 \mathrm{~h}$ of reaction time at room temperature using ligninolytic enzymes, whose conversion rate was $4.5 \%$ higher than that obtained by $4 \%$ alkali solution (Bilal et al., 2017c).

\section{Conclusion}


In the context of sustainable technologies, enzymes are presented as biodegradable biological agents having the ability to catalyze a wide variety of processes in water and organic media. The present review emphasized that an enzymatic approach based on peroxidase activity is a promising method for various environmental and biotechnological applications, and have a considerable potential in the energy transition. The characterization of these enzymes and the researches carried out on their mechanism of action, have facilitated the development and the design of various insoluble biocatalytic constructions achieved by different immobilization strategies. These advances made in the field of protein engineering allow stability, or even an improvement, in the catalytic performances of the biocatalyst, which leads to a significant reduction in the cost of the desired application. In addition to improved catalytic properties, immobilized peroxidases are green, eco-friendly and effective tools for the elimination of environmentally persistent aromatics in different types of media without producing additional waste. Moreover, these biological catalysts, derived from renewable and sustainable raw material, offer a certain operating versatility, both in the bioremediation of ecosystems and in the monitoring and detection of target compounds via their incorporation into biosensors. From a biotechnological point of view, white-rot fungi ligninolytic enzymes including MnP, LiP and VP, are of major interest for biofuel production processes. Indeed, these enzymes may have a promising future in biorefineries for the conversion of ligninocellulosic biomass into bioethanol. In conclusion, peroxidases fit perfectly with the ambition of economic transition from classical models to a system based on a circular economy. Nevertheless, it is important to note the considerable gap between the use of these green catalysts on a laboratory scale and industrial scale, which is 
often associated with the high amounts of enzymes required for a given application. This is why enzyme/carrier improvements or modifications should be focused on:

Design of materials with good chemical and mechanical resistance with high protein retention capacity.

$>$ Combining medium engineering and protein engineering for certain applications requiring the use of an organic phase.

$>$ Develop an oriented immobilization of enzymes to ensure a maximum number of active sites available for substrate reception.

Finding hydrogen peroxide substituents, in particular for applications in hydrophobic organic medium.

$>$ For organic phase use, a development of hybrid membrane with delivery system from embedded hollow fiber, where the hallow fiber is hydrophilic while the rest of the matrix is hydrophobic, $\mathrm{H}_{2} \mathrm{O}_{2}$ diffuses from hallow fiber into the porous matrix at the interface where the enzymes are grafted and solubilizes to its capacity into the organic phase.

$>$ In the case of VOCs, a conception of hydrophobic biomass capable to preserve enzyme from denaturation and achieving gaseous effluent "absorption" in the same matrix for its biotransformation. 


\section{Acknowledgments}

The Ministry of Higher Education and Scientific Research of Algeria and Campus

France are gratefully acknowledged for providing K.Sellami with Profas B+ grant $(933290 A)$.

\section{References}

Adrio, J. L., \& Demain, A. L. (2014). Microbial enzymes: tools for biotechnological processes. Biomolecules, 4(1), 117-139. https://doi.org/10.3390/biom4010117

Ai, J, Zhang, W., Liao, G. Y., Xia, H., \& Wang, D. (2016). Immobilization of horseradish peroxidase enzymes on hydrous-titanium and its application for phenol removal. RSC Advances, 6(44), 38117-38123. 
https://doi.org/10.1039/C6RA02397E

Ai, Jing, Zhang, W., Liao, G., Xia, H., \& Wang, D. (2017). NH2[sbnd]Fe3O4@SiO2 supported peroxidase catalyzed $\mathrm{H} 2 \mathrm{O} 2$ for degradation of endocrine disrupter from aqueous solution: Roles of active radicals and NOMs. Chemosphere, 186, 733-742. https://doi.org/10.1016/j.chemosphere.2017.08.039

Al-Maqdi, K. A., Hisaindee, S., Rauf, M. A., \& Ashraf, S. S. (2018). Detoxification and degradation of sulfamethoxazole by soybean peroxidase and UV $+\mathrm{H} 2 \mathrm{O} 2$ remediation approaches. Chemical Engineering Journal, 352, 450-458. https://doi.org/10.1016/j.cej.2018.07.036

Alemzadeh, I., \& Nejati, S. (2009). Phenols removal by immobilized horseradish peroxidase. Journal of Hazardous Materials, 166, 1082-1086. https://doi.org/10.1016/j.jhazmat.2008.12.026

Ali, L., Algaithi, R., Habib, H. M., Souka, U., Rauf, M. A., \& Ashraf, S. S. (2013). Soybean peroxidase-mediated degradation of an azo dye- A detailed mechanistic study. BMC Biochemistry, 14(1). https://doi.org/10.1186/1471-209114-35

Anderson, J. O., Thundiyil, J. G., \& Stolbach, A. (2012). Clearing the Air: A Review of the Effects of Particulate Matter Air Pollution on Human Health. Journal of Medical Toxicology, 8(2), 166-175. https://doi.org/10.1007/s13181-011-0203-1

Anjaneyulu, Y., Sreedhara Chary, N., \& Samuel Suman Raj, D. (2005). Decolourization of industrial effluents - Available methods and emerging technologies - A review. Reviews in Environmental Science and Biotechnology, 4(4), 245-273. https://doi.org/10.1007/s11157-005-1246-z 
Apostol, I., Heinstein, P. F., \& Low, P. S. (1989). Rapid Stimulation of an Oxidative Burst during Elicitation of Cultured Plant Cells. Plant Physiology, 90(1), 109-116. https://doi.org/10.1104/pp.90.1.109

Archer, E., Petrie, B., Kasprzyk-Hordern, B., \& Wolfaardt, G. M. (2017). The fate of pharmaceuticals and personal care products (PPCPs), endocrine disrupting contaminants (EDCs), metabolites and illicit drugs in a WWTW and environmental waters. Chemosphere, 174, 437-446. https://doi.org/10.1016/j.chemosphere.2017.01.101

Asgher, M., Ahmad, Z., \& lqbal, H. M. N. (2013). Alkali and enzymatic delignification of sugarcane bagasse to expose cellulose polymers for saccharification and bioethanol production. Industrial Crops and Products, 44, 488-495. https://doi.org/10.1016/j.indcrop.2012.10.005

Ashraf, H., \& Husain, Q. (2011). Application of immobilized peroxidase for the removal of $p$-bromophenol from polluted water in batch and continuous processes. Journal of Water Reuse and Desalination, 1(1), 52-60. https://doi.org/10.2166/wrd.2011.017

Auriol, M., Filali-Meknassi, Y., Tyagi, R. D., \& Adams, C. D. (2007). Oxidation of natural and synthetic hormones by the horseradish peroxidase enzyme in wastewater. Chemosphere, 68(10), 1830-1837. https://doi.org/10.1016/j.chemosphere.2007.03.045

Azizi, A., Abouseoud, M., \& Ahmedi, A. (2014). Phenol removal by soluble and alginate entrapped turnip peroxidase. Journal of Biochemical Technology, 5(4), 795-800.

Azizi, A., Abouseoud, M., \& Amrane, A. (2017). Phenol removal by a sequential 
combined fenton-enzymatic process. Nature Environment and Pollution

Technology, 16(1), 321-330.

Bakalovic, N., Passardi, F., loannidis, V., Cosio, C., Penel, C., Falquet, L., \& Dunand,

C. (2006). PeroxiBase: A class III plant peroxidase database. Phytochemistry, 67(6), 534-539. https://doi.org/10.1016/j.phytochem.2005.12.020

Bayramoǧlu, G., \& Arica, M. Y. (2008). Enzymatic removal of phenol and pchlorophenol in enzyme reactor: Horseradish peroxidase immobilized on magnetic beads. Journal of Hazardous Materials, 156(1-3), 148-155. https://doi.org/10.1016/j.jhazmat.2007.12.008

Béchohra, I., Couvert, A., \& Amrane, A. (2015). Absorption and biodegradation of toluene: Optimization of its initial concentration and the biodegradable nonaqueous phase liquid volume fraction. International Biodeterioration and Biodegradation, 104, 350-355. https://doi.org/10.1016/j.ibiod.2015.07.004

Besharati Vineh, M., Saboury, A. A., Poostchi, A. A., \& Mamani, L. (2018). Physical Adsorption of Horseradish Peroxidase on Reduced Graphene Oxide Nanosheets Functionalized by Amine: A Good System for Biodegradation of High Phenol Concentration in Wastewater. International Journal of Environmental Research, 12(1), 45-57. https://doi.org/10.1007/s41742-018-0067-1

Besharati Vineh, M., Saboury, A. A., Poostchi, A. A., Rashidi, A. M., \& Parivar, K. (2018). Stability and activity improvement of horseradish peroxidase by covalent immobilization on functionalized reduced graphene oxide and biodegradation of high phenol concentration. International Journal of Biological Macromolecules, 106, 1314-1322. https://doi.org/10.1016/j.ijbiomac.2017.08.133

Bilal, M., Adeel, M., Rasheed, T., \& lqbal, H. M. N. (2019). Multifunctional metal- 
organic frameworks-based biocatalytic platforms: Recent developments and future prospects. Journal of Materials Research and Technology, 8(2), 23592371. https://doi.org/10.1016/j.jmrt.2018.12.001

Bilal, M., Asgher, M., lqbal, H. M. N., \& Ramzan, M. (2017). Enhanced Bio-ethanol Production from Old Newspapers Waste Through Alkali and Enzymatic Delignification. Waste and Biomass Valorization, 8(7), 2271-2281. https://doi.org/10.1007/s12649-017-9871-7

Bilal, M., Asgher, M., Parra-Saldivar, R., Hu, H., Wang, W., Zhang, X., \& Iqbal, H. M. N. (2017). Immobilized ligninolytic enzymes: An innovative and environmental responsive technology to tackle dye-based industrial pollutants - A review. Science of the Total Environment, 576, 646-659. https://doi.org/10.1016/j.scitotenv.2016.10.137

Bilal, M., Ashraf, S. S., Ferreira, L. F. R., Cui, J., Lou, W. Y., Franco, M., \& lqbal, H. M. N. (2020). Nanostructured materials as a host matrix to develop robust peroxidases-based nanobiocatalytic systems. International Journal of Biological Macromolecules, 162, 1906-1923.

https://doi.org/10.1016/j.ijbiomac.2020.08.122

Bilal, M., Iqbal, M., Hu, H., \& Zhang, X. (2016). Mutagenicity and cytotoxicity assessment of biodegraded textile effluent by Ca-alginate encapsulated manganese peroxidase. Biochemical Engineering Journal, 109, 153-161. https://doi.org/10.1016/j.bej.2016.01.020

Bilal, M., Rasheed, T., lqbal, H. M. N., Hu, H., Wang, W., \& Zhang, X. (2018). Horseradish peroxidase immobilization by copolymerization into cross-linked polyacrylamide gel and its dye degradation and detoxification potential. 
International Journal of Biological Macromolecules, 113(2017), 983-990.

https://doi.org/10.1016/j.ijbiomac.2018.02.062

Bilal, M., Rasheed, T., Zhao, Y., \& lqbal, H. M. N. (2019). Agarose-chitosan hydrogelimmobilized horseradish peroxidase with sustainable bio-catalytic and dye degradation properties. International Journal of Biological Macromolecules, 124, 742-749. https://doi.org/10.1016/j.ijbiomac.2018.11.220

Bilal, M., Rasheed, T., Zhao, Y., Iqbal, H. M. N., \& Cui, J. (2018). "Smart” chemistry and its application in peroxidase immobilization using different support materials. International Journal of Biological Macromolecules, 119, 278-290. https://doi.org/10.1016/j.ijbiomac.2018.07.134

Bódalo, A., Gómez, J. L., Gómez, E., Bastida, J., \& Máximo, M. F. (2006). Comparison of commercial peroxidases for removing phenol from water solutions. Chemosphere, 63(4), 626-632.

https://doi.org/10.1016/j.chemosphere.2005.08.007

Borja, J., Taleon, D. M., Auresenia, J., \& Gallardo, S. (2005). Polychlorinated biphenyls and their biodegradation. Process Biochemistry, 40(6), 1999-2013. https://doi.org/10.1016/j.procbio.2004.08.006

Boucherit, N., Abouseoud, M., \& Adour, L. (2013). Degradation of direct azo dye by Cucurbita pepo free and immobilized peroxidase. Journal of Environmental Sciences (China), 25(6), 1235-1244. https://doi.org/10.1016/S10010742(12)60102-8

Camarero, S., Sarkar, S., Ruiz-Dueñas, F. J., Martínez, M. J., \& Martínez, Á. T. (1999). Description of a versatile peroxidase involved in the natural degradation of lignin that has both manganese peroxidase and lignin peroxidase substrate 
interaction sites. Journal of Biological Chemistry, 274(15), 10324-10330.

https://doi.org/10.1074/jbc.274.15.10324

Celebi, M., Kaya, M. A., Altikatoglu, M., \& Yildirim, H. (2013). Enzymatic decolorization of anthraquinone and diazo dyes using horseradish peroxidase enzyme immobilized onto various polysulfone supports. Applied Biochemistry and Biotechnology, 171(3), 716-730. https://doi.org/10.1007/s12010-013-0377-x

Chang, Q., Huang, J., Ding, Y., \& Tang, H. (2016). Catalytic oxidation of phenol and 2,4-dichlorophenol by using horseradish peroxidase immobilized on graphene oxide/Fe3O4. Molecules, 21(8). https://doi.org/10.3390/molecules21081044

Chen, X., Guo, C., \& Kong, J. (2012). Oxidative stress in neurodegenerative diseases. Neural Regeneration Research, 7(5), 376-385. https://doi.org/https://doi.org/10.3969/j.issn.1673-5374.2012.05.009

Chen, S., Yuan, R., Chai, Y., \& Hu, F. (2013). Electrochemical sensing of hydrogen peroxide using metal nanoparticles: A review. Microchimica Acta, 180(1-2), 1532. https://doi.org/10.1007/s00604-012-0904-4

Chen, Z., \& Wan, C. (2017). Biological valorization strategies for converting lignin into fuels and chemicals. Renewable and Sustainable Energy Reviews, 73(March 2016), 610-621. https://doi.org/10.1016/j.rser.2017.01.166

Choinowski, T., Blodig, W., Winterhalter, K. H., \& Piontek, K. (1999). The crystal structure of lignin peroxidase at $1.70 \AA$ resolution reveals a hydroxy group on the $C(\beta)$ of tryptophan 171: A novel radical site formed during the redox cycle. Journal of Molecular Biology, 286(3), 809-827. https://doi.org/10.1006/jmbi.1998.2507 
Colosi, L. M., Burlingame, D. J., Huang, Q., \& Weber, W. J. (2007). Peroxidasemediated removal of a polychlorinated biphenyl using natural organic matter as the sole cosubstrate. Environmental Science and Technology, 41(3), 891-896. https://doi.org/10.1021/es061616c

Conesa, A., Punt, P. J., \& Van Den Hondel, C. A. M. J. J. (2002). Fungal peroxidases: Molecular aspects and applications. Journal of Biotechnology, 93(2), 143-158. https://doi.org/10.1016/S0168-1656(01)00394-7

Cui, J., Cui, L., Jia, S., Su, Z., \& Zhang, S. (2016). Hybrid Cross-Linked Lipase Aggregates with Magnetic Nanoparticles: A Robust and Recyclable Biocatalysis for the Epoxidation of Oleic Acid. In Journal of Agricultural and Food Chemistry (Vol. 64, Issue 38). https://doi.org/10.1021/acs.jafc.6b01939

Cui, J. D., \& Jia, S. R. (2013). Optimization protocols and improved strategies of cross-linked enzyme aggregates technology: Current development and future challenges. Critical Reviews in Biotechnology, 35(1), 15-28. https://doi.org/10.3109/07388551.2013.795516

Cui, J. D., Li, L. L., \& Zhao, Y. M. (2014). Simple technique for preparing stable and recyclable cross-linked enzyme aggregates with crude-pored microspherical silica core. Industrial and Engineering Chemistry Research, 53(42), 1617616182. https://doi.org/10.1021/ie5021206

Dai, Z., Xu, X., Wu, L., \& Ju, H. (2005). Detection of trace phenol based on mesoporous silica derived tyrosinase-peroxidase biosensor. Electroanalysis, 17(17), 1571-1577. https://doi.org/10.1002/elan.200403256

Dargahi, A., Mohammadi, M., Amirian, F., Karami, A., \& Almasi, A. (2017). Phenol removal from oil refinery wastewater using anaerobic stabilization pond modeling 
and process optimization using response surface methodology (RSM).

Desalination and Water Treatment, 87(May), 199-208.

https://doi.org/10.5004/dwt.2017.21064

Dec, J., \& Bollag, J. M. (1990). Detoxification of substituted phenols by oxidoreductive enzymes through polymerization reactions. Archives of Environmental Contamination and Toxicology, 19(4), 543-550. https://doi.org/10.1007/BF01059073

Devi, A., Singh, A., Bajar, S., Pant, D., \& Din, Z. U. (2021). Ethanol from lignocellulosic biomass: An in-depth analysis of pre-treatment methods, fermentation approaches and detoxification processes. Journal of Environmental Chemical Engineering, 9(5), 105798. https://doi.org/10.1016/j.jece.2021.105798

Eibes, G., Lú-Chau, T., Feijoo, G., Moreira, M. T., \& Lema, J. M. (2005). Complete degradation of anthracene by Manganese Peroxidase in organic solvent mixtures. Enzyme and Microbial Technology, 37(4), 365-372. https://doi.org/10.1016/j.enzmictec.2004.02.010

Eibes, Gemma, Cajthaml, T., Moreira, M. T., Feijoo, G., \& Lema, J. M. (2006). Enzymatic degradation of anthracene, dibenzothiophene and pyrene by manganese peroxidase in media containing acetone. Chemosphere, 64(3), 408414. https://doi.org/10.1016/j.chemosphere.2005.11.075

Eibes, Gemma, McCann, C., Pedezert, A., Moreira, M. T., Feijoo, G., \& Lema, J. M. (2010). Study of mass transfer and biocatalyst stability for the enzymatic degradation of anthracene in a two-phase partitioning bioreactor. Biochemical Engineering Journal, 51(1-2), 79-85. https://doi.org/10.1016/j.bej.2010.05.006

Ertan, H., Siddiqui, K. S., Muenchhoff, J., Charlton, T., \& Cavicchioli, R. (2012). 
Kinetic and thermodynamic characterization of the functional properties of a hybrid versatile peroxidase using isothermal titration calorimetry: Insight into manganese peroxidase activation and lignin peroxidase inhibition. Biochimie, 94(5), 1221-1231. https://doi.org/10.1016/j.biochi.2012.02.012

Falade, A. O., Nwodo, U. U., Iweriebor, B. C., Green, E., Mabinya, L. V., \& Okoh, A. I. (2017). Lignin peroxidase functionalities and prospective applications. MicrobiologyOpen, 6(1), 1-14. https://doi.org/10.1002/mbo3.394

Fournier, D., Halasz, A., Spanggord, R. J., Bottaro, J. C., Hawari, J., International, S. R. I., Park, M., \& Icrobiol, A. P. P. L. E. N. M. (2004). Biodegradation of the hexahydro-1,3,5-Trinitro-1,3,5-Triazine ring Cleavage Product 4-Nitro-2 , 4Diazabutanal by Phanerochaete chrysosporium. Applied and Environmental Microbiology, 70(2), 1123-1128. https://doi.org/10.1128/AEM.70.2.1123

Furukawa, T., Bello, F. O., \& Horsfall, L. (2014). Microbial enzyme systems for lignin degradation and their transcriptional regulation. Frontiers in Biology, 9(6), 448471. https://doi.org/10.1007/s11515-014-1336-9

Garlapati, V. K., Chandel, A. K., Kumar, S. P. J., Sharma, S., Sevda, S., Ingle, A. P., \& Pant, D. (2020). Circular economy aspects of lignin: Towards a lignocellulose biorefinery. Renewable and Sustainable Energy Reviews, 130(June), 109977. https://doi.org/10.1016/j.rser.2020.109977

Gholami-Borujeni, F., Mahvi, A. H., Nasseri, S., Faramarzi, M. A., Nabizadeh, R., \& Alimohammadi, M. (2011). Enzymatic treatment and detoxification of acid orange 7 from textile wastewater. Applied Biochemistry and Biotechnology, 165(5-6), 1274-1284. https://doi.org/10.1007/s12010-011-9345-5

Global Markets for Enzymes in Industrial Applications 2021-2026. (n.d.). 
https://www.researchandmarkets.com/reports/5393441/global-markets-forenzymes-in-industrial. Retrieved August 2, 2021, from https://www.researchandmarkets.com/reports/5393441/global-markets-forenzymes-in-industrial

Gómez, E., Máximo, M. F., Montiel, M. C., Gómez, M., Murcia, M. D., \& Ortega, S. (2012). Continuous tank reactors in series: An improved alternative in the removal of phenolic compounds with immobilized peroxidase. Environmental Technology, 33(1), 103-111. https://doi.org/10.1080/09593330.2011.551841

Govere, E. M., Tonegawa, M., Bruns, M. A., Wheeler, E. F., Heinemann, P. H., Kephart, K. B., \& Dec, J. (2005). Deodorization of swine manure using minced horseradish roots and peroxides. Journal of Agricultural and Food Chemistry, 53(12), 4880-4889. https://doi.org/10.1021/jf0404290

Govere, E. M., Tonegawa, M., Bruns, M. A., Wheeler, E. F., Kephart, K. B., Voigt, J. W., \& Dec, J. (2007). Using minced horseradish roots and peroxides for the deodorization of swine manure: A pilot scale study. Bioresource Technology, 98(6), 1191-1198. https://doi.org/10.1016/j.biortech.2006.05.012

Hailei, W., Ping, L., Min, P., Zhijun, Z., Guangli, Y., Guosheng, L., \& Jianming, Y. (2009). Rapid decolourization of azo dyes by a new isolated higher manganese peroxidase producer: Phanerochaete sp. HSD. Biochemical Engineering Journal, 46(3), 327-333. https://doi.org/10.1016/j.bej.2009.06.008

Hamelinck, C. N., Van Hooijdonk, G., \& Faaij, A. P. C. (2005). Ethanol from lignocellulosic biomass: Techno-economic performance in short-, middle- and long-term. Biomass and Bioenergy, 28(4), 384-410.

https://doi.org/10.1016/j.biombioe.2004.09.002 
Hanefeld, U., Gardossi, L., \& Magner, E. (2009). Understanding enzyme immobilisation. Chemical Society Reviews, 38(2), 453-468. https://doi.org/10.1039/b711564b

Haritash, A. K., \& Kaushik, C. P. (2009). Biodegradation aspects of Polycyclic Aromatic Hydrocarbons (PAHs): A review. Journal of Hazardous Materials, 169(1-3), 1-15. https://doi.org/10.1016/j.jhazmat.2009.03.137

Henriksen, A., Smith, A. T., \& Gajhede, M. (1999). The structures of the horseradish peroxidase C-ferulic acid complex and the ternary complex with cyanide suggest how peroxidases oxidize small phenolic substrates. Journal of Biological Chemistry, 274(49), 35005-35011. https://doi.org/10.1074/jbc.274.49.35005

Hossain, L., Sarker, S. K., \& Khan, M. S. (2018). Evaluation of present and future wastewater impacts of textile dyeing industries in Bangladesh. Environmental Development, 26, 23-33. https://doi.org/10.1016/j.envdev.2018.03.005

Huang, Q., Selig, H., \& Weber, W. J. (2002). Peroxidase-catalyzed oxidative coupling of phenols in the presence of geosorbents: Rates of Non-extractable Product Formation. Environmental Science \& Technology, 36(4), 596-602. https://doi.org/10.1021/bk-2005-0904.ch003

Husain, Q. (2006). Potential applications of the oxidoreductive enzymes in the decolorization and detoxification of textile and other synthetic dyes from polluted water: A review. Critical Reviews in Biotechnology, 26(4), 201-221. https://doi.org/10.1080/07388550600969936

Husain, Q. (2010). Peroxidase mediated decolorization and remediation of wastewater containing industrial dyes: A review. Reviews in Environmental Science and Biotechnology, 9(2), 117-140. https://doi.org/10.1007/s11157-009- 
9184-9

Husain, Q., \& Ulber, R. (2011). Immobilized peroxidase as a valuable tool in the remediation of aromatic pollutants and xenobiotic compounds: A review. Critical Reviews in Environmental Science and Technology, 41(8), 770-804. https://doi.org/10.1080/10643380903299491

Ito, T., Adachi, Y., Yamanashi, Y., \& Shimada, Y. (2016). Long-term natural remediation process in textile dye-polluted river sediment driven by bacterial community changes. Water Research, 100, 458-465. https://doi.org/10.1016/j.watres.2016.05.050

Kalsoom, U., Ashraf, S. S., Meetani, M. A., Rauf, M. A., \& Bhatti, H. N. (2013). Mechanistic study of a diazo dye degradation by Soybean Peroxidase. Chemistry Central Journal, 7(1), 1-10. https://doi.org/10.1186/1752-153X-7-93

Karigar, C. S., \& Rao, S. S. (2011). Role of microbial enzymes in the bioremediation of pollutants: A review. Enzyme Research, 2011(1). https://doi.org/10.4061/2011/805187

Kazunga, C., Aitken, M. D., \& Gold, A. (1999). Primary product of the horseradish peroxidase-catalyzed oxidation of pentachlorophenol. Environmental Science and Technology, 33(9), 1408-1412. https://doi.org/10.1021/es981126n

Kim, G. Y., Lee, K. B., Cho, S. H., Shim, J., \& Moon, S. H. (2005). Electroenzymatic degradation of azo dye using an immobilized peroxidase enzyme. Journal of Hazardous Materials, 126(1-3), 183-188. https://doi.org/10.1016/j.jhazmat.2005.06.023

Kinne, M., Zeisig, C., Ullrich, R., Kayser, G., Hammel, K. E., \& Hofrichter, M. (2010). 
Stepwise oxygenations of toluene and 4-nitrotoluene by a fungal peroxygenase. Biochemical and Biophysical Research Communications, 397(1), 18-21. https://doi.org/10.1016/j.bbrc.2010.05.036

Köller, G., Möder, M., \& Czihal, K. (2000). Peroxidative degradation of selected PCB: A mechanistic study. Chemosphere, 41(12), 1827-1834. https://doi.org/10.1016/S0045-6535(00)00132-6

Kong, W., Fu, X., Wang, L., Alhujaily, A., Zhang, J., Ma, F., Zhang, X., \& Yu, H. (2017). A novel and efficient fungal delignification strategy based on versatile peroxidase for lignocellulose bioconversion. Biotechnology for Biofuels, 10(1), 115. https://doi.org/10.1186/s13068-017-0906-x

Krainer, F. W., \& Glieder, A. (2015). An updated view on horseradish peroxidases: recombinant production and biotechnological applications. Applied Microbiology and Biotechnology, 99(4), 1611-1625. https://doi.org/10.1007/s00253-014-63467

Kraus, J. J., Munir, I. Z., McEldoon, J. P., Clark, D. S., \& Dordick, J. S. (1999). Oxidation of polycyclic aromatic hydrocarbons catalyzed by soybean peroxidase. Applied Biochemistry and Biotechnology - Part A Enzyme Engineering and Biotechnology, 80(3), 221-230. https://doi.org/10.1385/ABAB:80:3:221

Kronenberg, M., Trably, E., Bernet, N., \& Patureau, D. (2017). Biodegradation of polycyclic aromatic hydrocarbons: Using microbial bioelectrochemical systems to overcome an impasse. Environmental Pollution, 231, 509-523. https://doi.org/10.1016/j.envpol.2017.08.048

Kumar, A., \& Singh, S. (2013). Directed evolution: Tailoring biocatalysts for industrial applications. Critical Reviews in Biotechnology, 33(4), 365-378. 
https://doi.org/10.3109/07388551.2012.716810

Leisola, M., Jokela, J., Pastinen, O., Turunen, O., \& Schoemaker, H. (2002).

Industrial use of enzymes. In Encyclopedia of Life Support Systems (EOLSS).

Oxfork. UK.

Leu, C., Singer, H., Stamm, C., Müller, S. R., \& Schwarzenbach, R. P. (2004).

Variability of herbicide losses from 13 fields to surface water within a small

catchment after a controlled herbicide application. Environmental Science and

Technology, 38(14), 3835-3841. https://doi.org/10.1021/es0499593

Leung, A., Shankar, P. M., \& Mutharasan, R. (2007). A review of fiber-optic

biosensors. Sensors and Actuators, B: Chemical, 125(2), 688-703.

https://doi.org/10.1016/j.snb.2007.03.010

Lhuissier, M., Couvert, A., Amrane, A., Kane, A., \& Audic, J. L. (2018).

Characterization and selection of waste oils for the absorption and biodegradation of VOC of different hydrophobicities. Chemical Engineering Research and Design, 138, 482-489.

https://doi.org/10.1016/j.cherd.2018.08.028

Li, S., Yang, X., Yang, S., Zhu, M., \& Wang, X. (2012). Technology prospecting on enzymes: Application, marketing and engineering. Computational and Structural Biotechnology Journal, 2(3), e201209017.

https://doi.org/10.5936/csbj.201209017

Liszkay, A., Kenk, B., \& Schopfer, P. (2003). Evidence for the involvement of cell wall peroxidase in the generation of hydroxyl radicals mediating extension growth. Planta, 217(4), 658-667. https://doi.org/10.1007/s00425-003-1028-1 
Liu, Y., Lu, S., Yan, X., Gao, S., Cui, X., \& Cui, Z. (2020). Life cycle assessment of petroleum refining process: A case study in China. Journal of Cleaner Production, 256, 120422. https://doi.org/10.1016/j.jclepro.2020.120422

Longoria, A., Tinoco, R., \& Vázquez-Duhalt, R. (2008). Chloroperoxidase-mediated transformation of highly halogenated monoaromatic compounds. Chemosphere, 72(3), 485-490. https://doi.org/10.1016/j.chemosphere.2008.03.006

Mashhadi, N., Taylor, K. E., Biswas, N., Meister, P., \& Gauld, J. W. (2019).

Oligomerization of 3-substituted quinolines by catalytic activity of soybean peroxidase as a wastewater treatment. Product formation and computational studies. Chemical Engineering Journal, 364(January), 340-348. https://doi.org/10.1016/j.cej.2019.01.184

McCauley, L. A., Anger, W. K., Keifer, M., Langley, R., Robson, M. G., \& Rohlman, D. (2006). Studying health outcomes in farmworker populations exposed to pesticides. Environmental Health Perspectives, 114(6), 953-960. https://doi.org/10.1289/ehp.8526

Mezzelani, M., Gorbi, S., \& Regoli, F. (2018). Pharmaceuticals in the aquatic environments: Evidence of emerged threat and future challenges for marine organisms. Marine Environmental Research, 140, 41-60. https://doi.org/10.1016/j.marenvres.2018.05.001

Mohammadi, S., Kargari, A., Sanaeepur, H., Abbassian, K., Najafi, A., \& Mofarrah, E. (2015). Phenol removal from industrial wastewaters: a short review. Desalination and Water Treatment, 53(8), 2215-2234. https://doi.org/10.1080/19443994.2014.883327

Mojiri, A., Zhou, J. L., Ohashi, A., Ozaki, N., \& Kindaichi, T. (2019). Comprehensive 
review of polycyclic aromatic hydrocarbons in water sources, their effects and treatments. Science of the Total Environment, 696, 133971.

https://doi.org/10.1016/j.scitotenv.2019.133971

Mougin, C., Laugero, C., Asther, M., Dubroca, J., Frasse, P., \& Asther, M. (1994).

Biotransformation of the herbicide atrazine by the white rot fungus

Phanerochaete chrysosporium. Applied and Environmental Microbiology, 60(2), 705-708. https://doi.org/10.1128/aem.60.2.705-708.1994

Muñoz, R., Villaverde, S., Guieysse, B., \& Revah, S. (2007). Two-phase partitioning bioreactors for treatment of volatile organic compounds. Biotechnology Advances, 25(4), 410-422. https://doi.org/10.1016/j.biotechadv.2007.03.005

Nakamoto, S., \& Machida, N. (1992). Phenol removal from aqueous solutions by peroxidase-catalyzed reaction using additives. Water Research, 26(1), 49-54. https://doi.org/10.1016/0043-1354(92)90110-P

Nguyen, H. H., \& Kim, M. (2017). An Overview of Techniques in Enzyme Immobilization. Applied Science and Convergence Technology, 26(6), 157-163. https://doi.org/10.5757/asct.2017.26.6.157

Nicell, J. A., Bewtra, J. K., Bewas, N., St. Pierre, C. C., \& Taylor, K. E. (1993). Enzyme catalyzed polymerization and precipitation of aromatic compounds from aqueous solution. Canadian Journal of Civil Engineering, 20(5), 725-735. https://doi.org/10.1139/193-097

Novick, S. J., \& Rozzell, J. D. (2005). Immobilization of Enzymes by Covalent Attachment. Microbial Enzymes and Biotransformations, 17, 247-271. https://doi.org/10.1385/1-59259-846-3:247 
Park, J. W., Dec, J., Kim, J. E., \& Bollag, J. M. (2000). Dehalogenation of xenobiotics as a consequence of binding to humic materials. Archives of Environmental Contamination and Toxicology, 38(4), 405-410. https://doi.org/10.1007/s002449910054

Parker, D. B., Cai, L., Kim, K. H., Hales, K. E., Spiehs, M. J., Woodbury, B. L., Atkin, A. L., Nickerson, K. W., \& Patefield, K. D. (2012). Reducing odorous VOC emissions from swine manure using soybean peroxidase and peroxides. Bioresource Technology, 124, 95-104. https://doi.org/10.1016/j.biortech.2012.08.031

Passardi, F., Bakalovic, N., Teixeira, F. K., Margis-Pinheiro, M., Penel, C., \& Dunand, C. (2007). Prokaryotic origins of the non-animal peroxidase superfamily and organelle-mediated transmission to eukaryotes. Genomics, 89(5), 567-579. https://doi.org/10.1016/j.ygeno.2007.01.006

Passardi, F., Theiler, G., Zamocky, M., Cosio, C., Rouhier, N., Teixera, F., MargisPinheiro, M., loannidis, V., Penel, C., Falquet, L., \& Dunand, C. (2007). PeroxiBase: The peroxidase database. Phytochemistry, 68(12), 1605-1611. https://doi.org/10.1016/j.phytochem.2007.04.005

Pizzul, L., Castillo, M. del P., \& Stenström, J. (2009). Degradation of glyphosate and other pesticides by ligninolytic enzymes. Biodegradation, 20(6), 751-759. https://doi.org/10.1007/s10532-009-9263-1

Pradeep, N. V., Anupama, S., Navya, K., Shalini, H. N., Idris, M., \& Hampannavar, U. S. (2015). Biological removal of phenol from wastewaters: a mini review. Applied Water Science, 5(2), 105-112. https://doi.org/10.1007/s13201-014-0176-8

Pylypchuk, I. V., Daniel, G., Kessler, V. G., \& Seisenbaeva, G. A. (2020). Removal of 
diclofenac, paracetamol, and carbamazepine from model aqueous solutions by magnetic sol-gel encapsulated horseradish peroxidase and lignin peroxidase composites. Nanomaterials, 10(2). https://doi.org/10.3390/nano10020282

Quilles Junior, J. C., Ferrarezi, A. L., Borges, J. P., Brito, R. R., Gomes, E., da Silva, R., Guisán, J. M., \& Boscolo, M. (2016). Hydrophobic adsorption in ionic medium improves the catalytic properties of lipases applied in the triacylglycerol hydrolysis by synergism. Bioprocess and Biosystems Engineering, 39(12), 1933-1943. https://doi.org/10.1007/s00449-016-1667-9

Rahemi, V., Trashin, S., Meynen, V., \& De Wael, K. (2016). An adhesive conducting electrode material based on commercial mesoporous titanium dioxide as a support for Horseradish peroxidase for bioelectrochemical applications. Talanta, 146(2015), 689-693. https://doi.org/10.1016/j.talanta.2015.06.041

Rappert, S., \& Müller, R. (2005). Odor compounds in waste gas emissions from agricultural operations and food industries. Waste Management, 25(9), 887-907. https://doi.org/10.1016/j.wasman.2005.07.008

Rasheed, T., Bilal, M., Nabeel, F., Adeel, M., \& lqbal, H. M. N. (2019).

Environmentally-related contaminants of high concern: Potential sources and analytical modalities for detection, quantification, and treatment. Environment International, 122(September 2018), 52-66.

https://doi.org/10.1016/j.envint.2018.11.038

Rosatto, S. S., Kubota, L. T., \& De Oliveira Neto, G. (1999). Biosensor for phenol based on the direct electron transfer blocking of peroxidase immobilising on silica-titanium. Analytica Chimica Acta, 390(1-3), 65-72. https://doi.org/10.1016/S0003-2670(99)00168-3 
Rüttimann-Johnson, C., \& Lamar, R. T. (1996). Polymerization of pentachlorophenol and ferulic acid by fungal extracellular lignin-degrading enzymes. Applied and Environmental Microbiology, 62(10), 3890-3893. https://doi.org/10.1128/aem.62.10.3890-3893.1996

Ruzgas, T., Csöregi, E., Emnéus, J., Gorton, L., \& Marko-Varga, G. (1996). Peroxidase-modified electrodes: Fundamentals and application. Analytica Chimica Acta, 330(2-3), 123-138. https://doi.org/10.1016/0003-2670(96)001699

S. Parveen, M. Asgher, M. B. (2020). Lignin peroxidase-based cross-linked enzyme aggregates (LiP-CLEAs) as robust biocatalytic materials for mitigation of textile dyes-contaminated aqueous solution. Environmental Technology \& Innovation, 101226. https://doi.org/10.1016/j.eti.2020.101226

Samokyszyn, V. M., Freeman, J. P., Maddipati, K. R., \& Lloyd, R. V. (1995). Peroxidase-Catalyzed Oxidation of Pentachlorophenol. Chemical Research in Toxicology, 8(3), 349-355. https://doi.org/10.1021/tx00045a005

Sassolas, A., Blum, L. J., \& Leca-Bouvier, B. D. (2012). Immobilization strategies to develop enzymatic biosensors. Biotechnology Advances, 30(3), 489-511. https://doi.org/10.1016/j.biotechadv.2011.09.003

Schwarzenbach, R. P., Egli, T., Hofstetter, T. B., Von Gunten, U., \& Wehrli, B. (2010). Global water pollution and human health. Annual Review of Environment and Resources, 35, 109-136. https://doi.org/10.1146/annurev-environ-100809125342

Seelbach, K., Van Deurzen, M. P. J., Van Rantwijk, F., Sheldon, R. A., \& Kragl, U. (1997). Improvement of the total turnover number and space-time yield for 
chloroperoxidase catalyzed oxidation. Biotechnology and Bioengineering, 55(2), 283-288. https://doi.org/10.1002/(SICI)1097-0290(19970720)55:2<283::AIDBIT6>3.0.CO;2-E

Sellami, K., Couvert, A., Nasrallah, N., Maachi, R., Tandjaoui, N., Abouseoud, M., \& Amrane, A. (2021). Bio-based and cost effective method for phenolic compounds removal using cross-linked enzyme aggregates. Journal of Hazardous Materials, 403(September 2020), 124021. https://doi.org/10.1016/j.jhazmat.2020.124021

Shakerian, F., Zhao, J., \& Li, S. P. (2020). Recent development in the application of immobilized oxidative enzymes for bioremediation of hazardous micropollutants - A review. Chemosphere, 239, 124716.

https://doi.org/10.1016/j.chemosphere.2019.124716

Sheldon, R. A., \& van Pelt, S. (2013). Enzyme immobilisation in biocatalysis: Why, what and how. Chemical Society Reviews, 42(15), 6223-6235. https://doi.org/10.1039/c3cs60075k

Singh, A., Billingsley, K. A., \& Ward, O. P. (2000). Transformation of polychlorinated biphenyls with oxidative enzymes. Bioprocess Engineering, 23(5), 421-425. https://doi.org/10.1007/s004499900121

Singh, B. D. (2007). Biotechnology expanding horizons. Kalyani publishers.

Singh, R., Kumar, M., Mittal, A., \& Mehta, P. K. (2016). Microbial enzymes: industrial progress in 21st century. 3 Biotech, 6(2). https://doi.org/10.1007/s13205-0160485-8

Singh, R. S., Singh, T., \& Pandey, A. (2019). Microbial enzymes-an overview. In 
Biomass, Biofuels, Biochemicals: Advances in Enzyme Technology. Elsevier

B.V. https://doi.org/10.1016/B978-0-444-64114-4.00001-7

Singhania, R. R., Patel, A. K., Thomas, L., Goswami, M., Giri, B. S., \& Pandey, A. (2015). Industrial Enzymes. In Industrial Biorefineries and White Biotechnology. Elsevier B.V. https://doi.org/10.1016/B978-0-444-63453-5.00015-X

Spasojević, M., Prodanović, O., Pantić, N., Popović, N., Balaž, A. M., \& Prodanović, R. (2019). The enzyme immobilization: carriers and immobilization methods. Journal of Engineering \& Processing Management, 11(2).

Speight, J. G. (2017). Removal of Organic Compounds From the Environment. In Environmental Organic Chemistry for Engineers. https://doi.org/10.1016/b978-0$12-804492-6.00009-5$

Sridhar, R., Ramanane, U. U., \& Rajasimman, M. (2018). ZnO nanoparticles Synthesis, characterization and its application for phenol removal from synthetic and pharmaceutical industry wastewater. Environmental Nanotechnology, Monitoring and Management, 10, 388-393. https://doi.org/10.1016/j.enmm.2018.09.003

Stadlmair, L. F., Letzel, T., Drewes, J. E., \& Grassmann, J. (2018). Enzymes in removal of pharmaceuticals from wastewater: A critical review of challenges, applications and screening methods for their selection. Chemosphere, 205, 649661. https://doi.org/10.1016/j.chemosphere.2018.04.142

Sun, Y., \& Cheng, J. (2002). Hydrolysis of lignocellulosic materials for ethanol production: A review. Bioresource Technology, 83(1), 1-11. https://doi.org/10.1016/S0960-8524(01)00212-7 
Szatkowski, L., Thompson, M. K., Kaminski, R., Franzen, S., \& Dybala-Defratyka, A. (2011). Oxidative dechlorination of halogenated phenols catalyzed by two distinct enzymes: Horseradish peroxidase and dehaloperoxidase. Archives of Biochemistry and Biophysics, 505(1), 22-32.

https://doi.org/10.1016/j.abb.2010.09.018

Tandjaoui, N., Abouseoud, M., Couvert, A., Amrane, A., \& Tassist, A. (2016). A new combined green method for 2-Chlorophenol removal using cross-linked Brassica rapa peroxidase in silicone oil. Chemosphere, 148, 55-60.

https://doi.org/10.1016/j.chemosphere.2016.01.021

Tandjaoui, N., Abouseoud, M., Couvert, A., Amrane, A., \& Tassist, A. (2019). A combination of absorption and enzymatic biodegradation: phenol elimination from aqueous and organic phase. Environmental Technology (United Kingdom), 40(5), 625-632. https://doi.org/10.1080/09593330.2017.1400110

Tandjaoui, N., Tassist, A., Abouseoud, M., Couvert, A., \& Amrane, A. (2015). Preparation and characterization of cross-linked enzyme aggregates (CLEAs) of Brassica rapa peroxidase. Biocatalysis and Agricultural Biotechnology, 4(2), 208-213. https://doi.org/10.1016/j.bcab.2014.12.002

Tandjaoui, N., Wolbert, D., Couvert, A., Abouseoud, M., Amrane, A., \& Tassist, A. (2020). An effective toluene removal from waste-air by a simple process based on absorption in silicone oil (PDMS) and cross-linked Brassica rapa peroxidase (BRP-CLEAs) catalysis in organic medium: Optimization with RSM.

Environmental Progress and Sustainable Energy, 39(4).

https://doi.org/10.1002/ep.13381

Tatsuma, T., Watanabe, T., \& Okawa, Y. (1989). Enzyme Monolayer- and Bilayer- 
Modified Tin Oxide Electrodes for the Determination of Hydrogen Peroxide and Glucose. Analytical Chemistry, 61(21), 2352-2355.

https://doi.org/10.1021/ac00196a007

Tatsumi, K., \& Wada, S. (1996). Communication to the Editor Removal of Chlorophenols from Wastewater. Biotechnology and Bioengineering, 51, $126-$ 130.

Thenmozhi, K., \& Narayanan, S. S. (2017). Horseradish peroxidase and toluidine blue covalently immobilized leak-free sol-gel composite biosensor for hydrogen peroxide. Materials Science and Engineering C, 70, 223-230. https://doi.org/10.1016/j.msec.2016.08.075

Tiwari, B., Sellamuthu, B., Ouarda, Y., Drogui, P., Tyagi, R. D., \& Buelna, G. (2017). Review on fate and mechanism of removal of pharmaceutical pollutants from wastewater using biological approach. Bioresource Technology, 224, 1-12. https://doi.org/10.1016/j.biortech.2016.11.042

Torres, E., Tinoco, R., \& Vazquez-Duhalt, R. (1997). Biocatalytic oxidation of polycyclic aromatic hydrocarbons in media containing organic solvents. Water Science and Technology, 36(10), 37-44. https://doi.org/10.1016/S02731223(97)00640-9

Touahar, I. E., Haroune, L., Ba, S., Bellenger, J. P., \& Cabana, H. (2014). Characterization of combined cross-linked enzyme aggregates from laccase, versatile peroxidase and glucose oxidase, and their utilization for the elimination of pharmaceuticals. Science of the Total Environment, 481(1), 90-99. https://doi.org/10.1016/j.scitotenv.2014.01.132

Ullrich, R., \& Hofrichter, M. (2007). Enzymatic hydroxylation of aromatic compounds. 
Cellular and Molecular Life Sciences, 64(3), 271-293.

https://doi.org/10.1007/s00018-007-6362-1

Van De Velde, F., Lourenço, N. D., Bakker, M., Van Rantwijk, F., \& Sheldon, R. A. (2000). Improved operational stability of peroxidases by coimmobilization with glucose oxidase. Biotechnology and Bioengineering, 69(3), 286-291. https://doi.org/10.1002/1097-0290(20000805)69:3<286::AID-BIT6>3.0.CO;2-R

Van De Velde, F., Van Rantwijk, F., \& Sheldon, R. A. (2001). Improving the catalytic performance of peroxidases in organic synthesis. TRENDS in Biotechnology, 19(2), 73-80. https://doi.org/https://doi.org/10.1016/S0167-7799(00)01529-8

Van Deurzen, M. P. J., Seelbach, K., Van Rantwijk, F., Kragl, U., \& Sheldon, R. A. (1997). Chloroperoxidase: Use of a hydrogen peroxide-stat for controlling reactions and improving enzyme performance. Biocatalysis and Biotransformation, 15(1), 1-16. https://doi.org/10.3109/10242429709003606

Vasileva, N., Godjevargova, T., Ivanova, D., \& Gabrovska, K. (2009). Application of immobilized horseradish peroxidase onto modified acrylonitrile copolymer membrane in removing of phenol from water. International Journal of Biological Macromolecules, 44(2), 190-194. https://doi.org/10.1016/j.ijbiomac.2008.12.002

Villegas, L. G. C., Mashhadi, N., Chen, M., Mukherjee, D., Taylor, K. E., \& Biswas, N. (2016). A Short Review of Techniques for Phenol Removal from Wastewater. Current Pollution Reports, 2(3), 157-167. https://doi.org/10.1007/s40726-016$0035-3$

Wagner, M., \& Nicell, J. A. (2001). Peroxidase-catalyzed removal of phenols from a petroleum refinery wastewater. Water Science and Technology, 43(2), 253-260. https://doi.org/10.2166/wst.2001.0097 
Wang, J., Liu, X., Liu, G., Zhang, Z., Wu, H., Cui, B., Bai, J., \& Zhang, W. (2019). Size effect of polystyrene microplastics on sorption of phenanthrene and nitrobenzene. Ecotoxicology and Environmental Safety, 173(December 2018), 331-338. https://doi.org/10.1016/j.ecoenv.2019.02.037

Wang, S., Fang, H., Wen, Y., Cai, M., Liu, W., He, S., \& Xu, X. (2015). Applications of HRP-immobilized catalytic beads to the removal of 2,4-dichlorophenol from wastewater. RSC Advances, 5(71), 57286-57292.

https://doi.org/10.1039/c5ra08688d

Ward, G., Hadar, Y., \& Dosoretz, C. G. (2001). Inactivation of lignin peroxidase during oxidation of the highly reactive substrate ferulic acid. Enzyme and Microbial Technology, 29(1), 34-41. https://doi.org/10.1016/S01410229(01)00336-2

Wen, X., Jia, Y., \& Li, J. (2010). Enzymatic degradation of tetracycline and oxytetracycline by crude manganese peroxidase prepared from Phanerochaete chrysosporium. Journal of Hazardous Materials, 177(1-3), 924-928. https://doi.org/10.1016/j.jhazmat.2010.01.005

Weng, J. K., Li, X., Bonawitz, N. D., \& Chapple, C. (2008). Emerging strategies of lignin engineering and degradation for cellulosic biofuel production. Current Opinion in Biotechnology, 19(2), 166-172. https://doi.org/10.1016/j.copbio.2008.02.014

Whitehead, T. R., \& Cotta, M. A. (2004). Isolation and Identification of HyperAmmonia Producing Bacteria from Swine Manure Storage Pits. Current Microbiology, 48(1), 20-26. https://doi.org/10.1007/s00284-003-4084-7

Wilberg, K., Assenhaimer, C., \& Rubio, J. (2002). Removal of aqueous phenol 
catalysed by a low purity soybean peroxidase. Journal of Chemical Technology and Biotechnology, 77(7), 851-857. https://doi.org/10.1002/jctb.646

Wong, D. W. S. (2009). Structure and action mechanism of ligninolytic enzymes. In Applied Biochemistry and Biotechnology (Vol. 157, Issue 2). https://doi.org/10.1007/s12010-008-8279-z

Xie, H., Hao, H., Xu, N., Liang, X., Gao, D., Xu, Y., Gao, Y., Tao, H., \& Wong, M. (2019). Pharmaceuticals and personal care products in water, sediments, aquatic organisms, and fish feeds in the Pearl River Delta: Occurrence, distribution, potential sources, and health risk assessment. Science of the Total Environment, 659, 230-239. https://doi.org/10.1016/j.scitotenv.2018.12.222

Yamada, K., Shibuya, T., Noda, M., Uchiyama, N., Kashiwada, A., Matsuda, K., \& Hirata, M. (2007). Influence of position of substituent groups on removal of chlorophenols and cresols by horseradish peroxidase and determination of optimum conditions. Bioscience, Biotechnology and Biochemistry, 71(10), 25032510. https://doi.org/10.1271/bbb.70298

Ye, F. X., Zhu, R. F., \& Li, Y. (2009). Deodorization of swine manure slurry using horseradish peroxidase and peroxides. Journal of Hazardous Materials, 167(13), 148-153. https://doi.org/10.1016/j.jhazmat.2008.12.096

Yu, J., Taylor, K. E., Zou, H., Biswas, N., \& Bewtra, J. K. (1994). Phenol Conversion and Dimeric Intermediates in Horseradish Peroxidase-Catalyzed Phenol Removal from Water. Environmental Science and Technology, 28(12), 21542160. https://doi.org/10.1021/es00061a025

Zaks, A., \& Dodds, D. R. (1995). Chloroperoxidase-Catalyzed Asymmetric Oxidations: Substrate Specificity and Mechanistic Study. Journal of the 
American Chemical Society, 117(42), 10419-10424.

https://doi.org/10.1021/ja00147a001

Zdarta, J., Nguyen, L. N., Jankowska, K., Jesionowski, T., \& Nghiem, L. D. (2021). A contemporary review of enzymatic applications in the remediation of emerging estrogenic compounds. Critical Reviews in Environmental Science and Technology, O(0), 1-30. https://doi.org/10.1080/10643389.2021.1889283

Zhang, X., Gao, B., Creamer, A. E., Cao, C., \& Li, Y. (2017). Adsorption of VOCs onto engineered carbon materials: A review. Journal of Hazardous Materials, 338, 102-123. https://doi.org/10.1016/j.jhazmat.2017.05.013

Zhu, D., Wu, Q., \& Wang, N. (2011). Industrial Enzymes. Comprehensive Biotechnology, Second Edition, 3, 3-13. https://doi.org/10.1016/B978-0-08088504-9.00182-3

Zucca, P., \& Sanjust, E. (2014). Inorganic materials as supports for covalent enzyme immobilization: Methods and mechanisms. Molecules, 19(9), 14139-14194. https://doi.org/10.3390/molecules190914139 


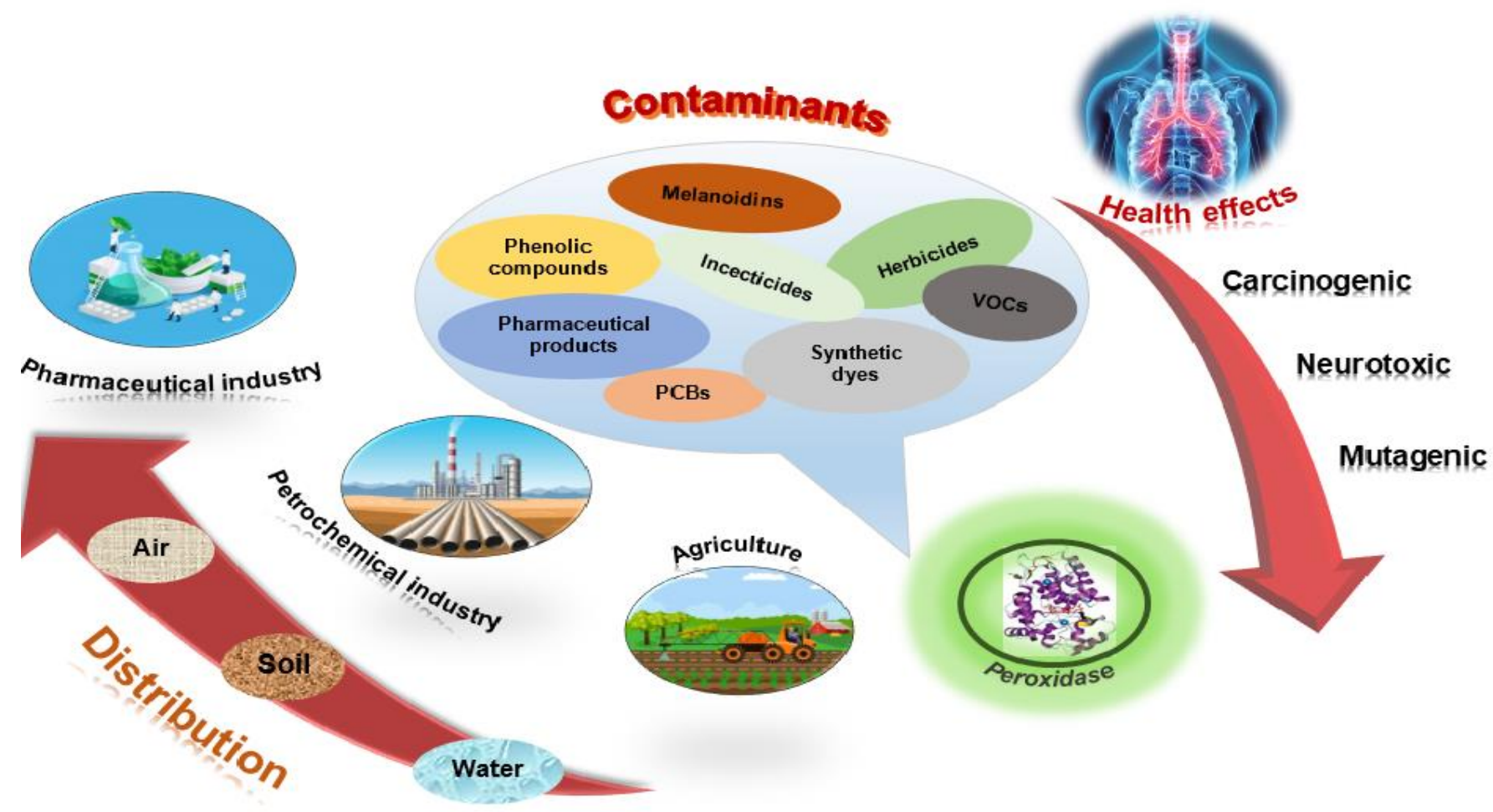

Fig. 1. Contaminants that can be treated by peroxidases, their distribution, source and the consequences related to their release into nature. 


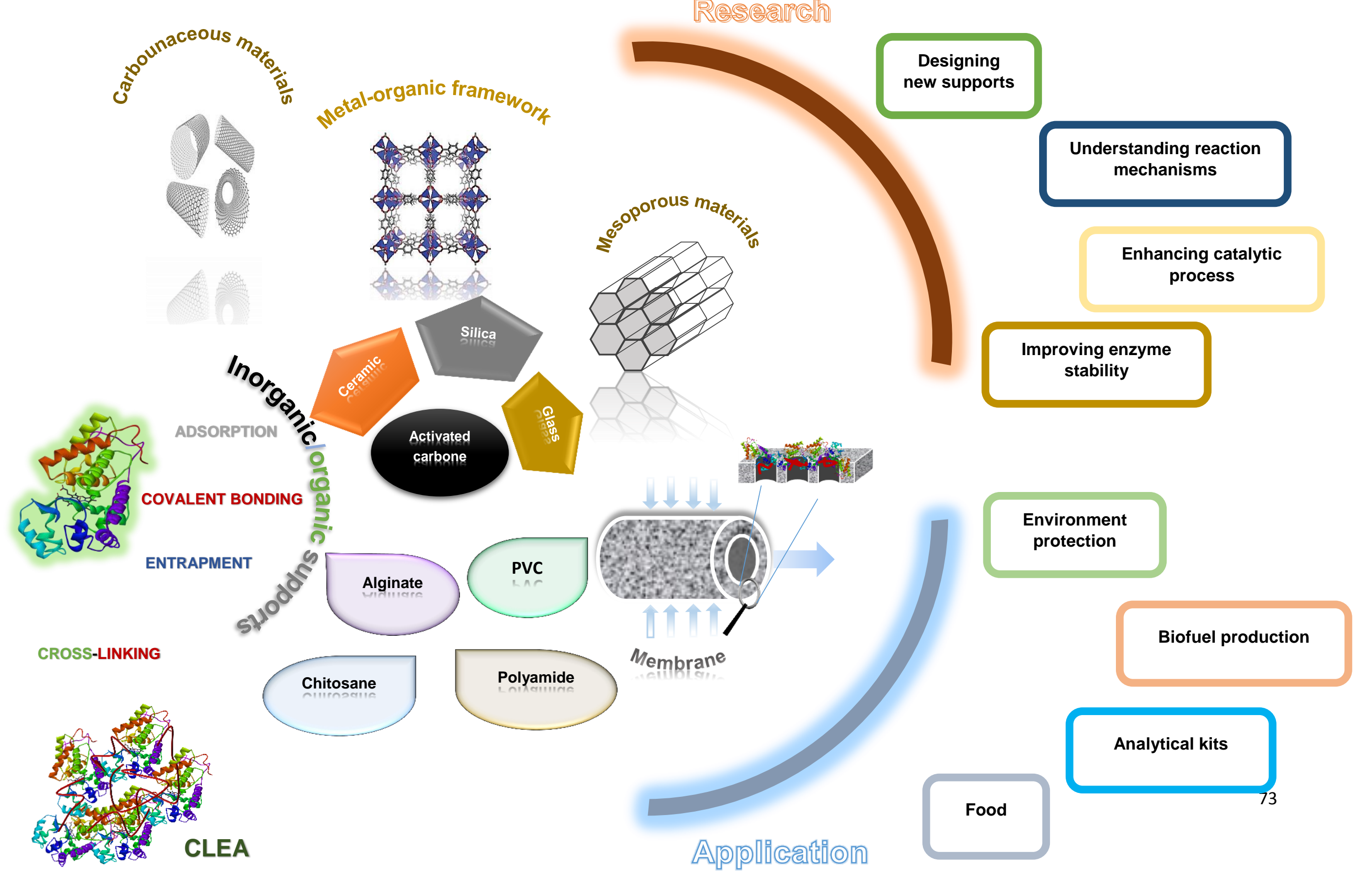


Fig. 2. Schematic illustration of immobilization strategies for efficient biocatalysis. 


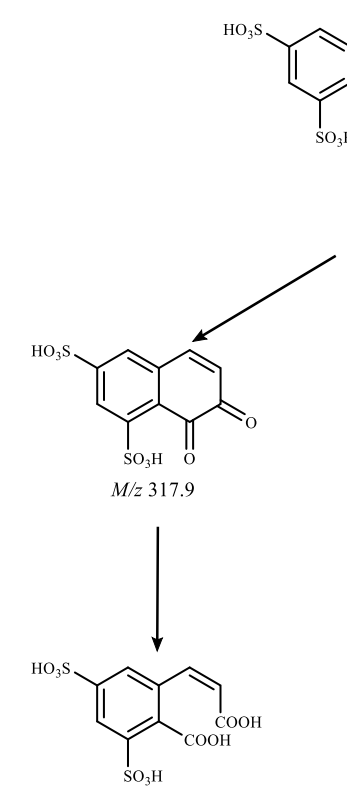

$M / 2351.9$

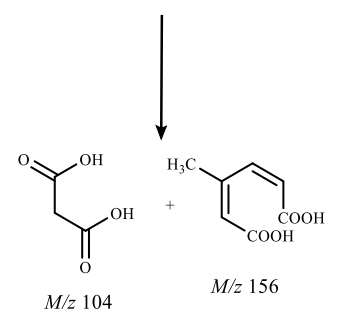

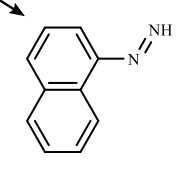

$M / z 155.0$
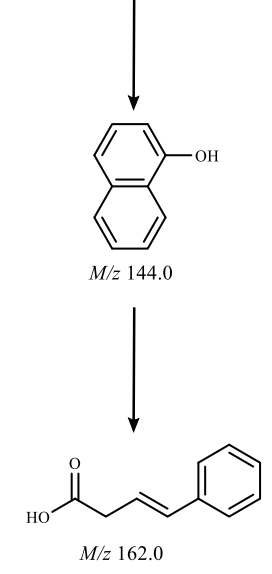

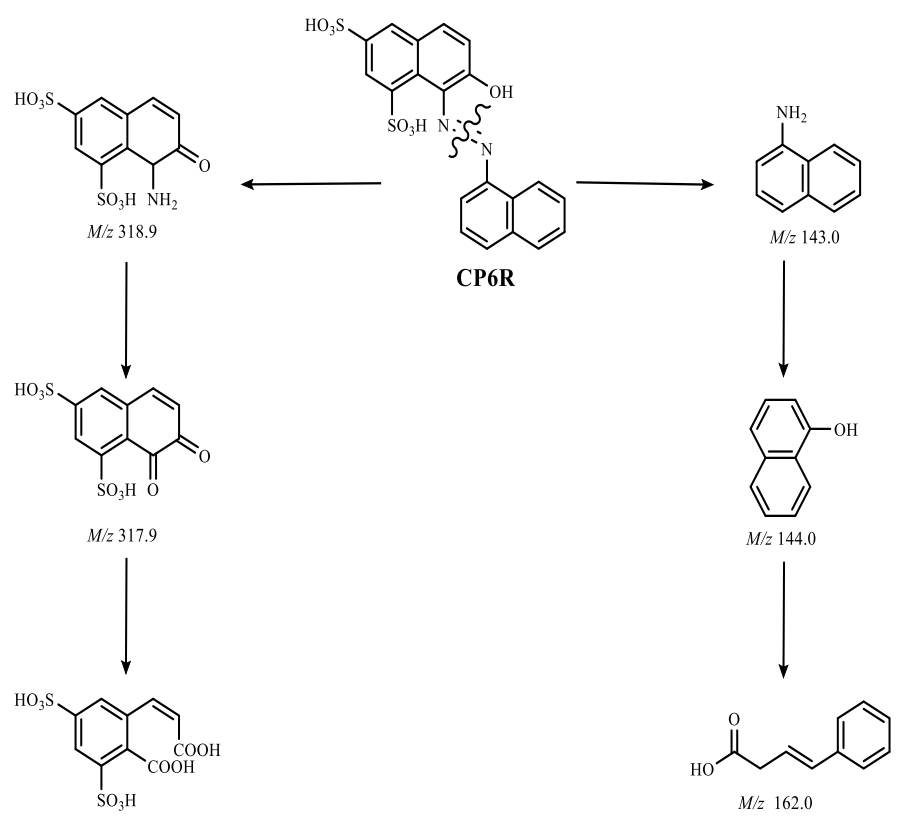

Fig. 3. Hypothetical reaction/breakdown pathways of CP6R by commercial soybean peroxidase, adapted from (Ali et al., 2013) 


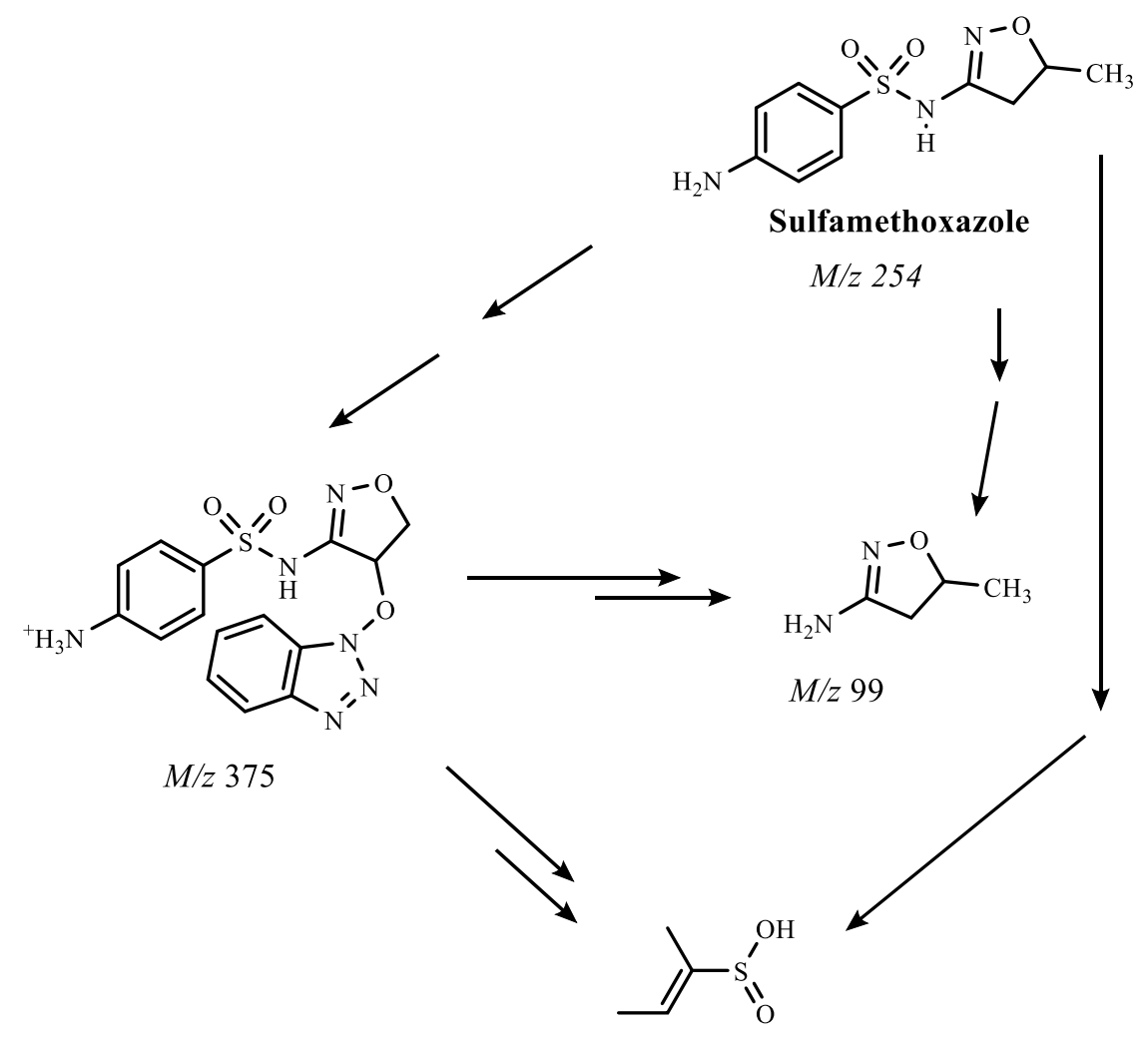

$M / z 120$

Fig. 4. Degradation pathways of sufamethoxazole by soybean peroxidase, adapted from (Al-Maqdi et al., 2018) 


\section{Table 1}

Sources and health effects of some typical contaminants.

\begin{tabular}{|c|c|c|c|}
\hline Sources & Typical contaminants & Health effects & Reference \\
\hline \multirow{3}{*}{ Petrochemical industry } & BTEXs & Carcinogenic, neurotoxic & Sun et al. (2021) \\
\hline & Phenols & Carcinogenic, phytotoxic & $\begin{array}{l}\text { Kottuparambil et al. } \\
\text { (2014); Sellami et al. } \\
\text { (2021) }\end{array}$ \\
\hline & $\mathrm{PAHs}$ & Carcinogenic, genotoxic & $\begin{array}{l}\text { Kronenberg et al. (2017); } \\
\text { Le Dû-Lacoste et al. } \\
\text { (2013) }\end{array}$ \\
\hline \multirow{3}{*}{ Agriculture/livestock } & $\begin{array}{c}\text { Organophosphorous } \\
\text { insecticides }\end{array}$ & $\begin{array}{l}\text { Loss of nerve function, } \\
\text { eventual death of the } \\
\text { animal }\end{array}$ & $\begin{array}{l}\text { Kapoor and Rajagopal } \\
\text { (2011) }\end{array}$ \\
\hline & Herbicides & $\begin{array}{l}\text { Reproductive problems, } \\
\text { malformations, } \\
\text { teratogenic }\end{array}$ & Gupta (2018) \\
\hline & $\begin{array}{l}\text { Odorant compounds of } \\
\text { swine manure }\end{array}$ & $\begin{array}{c}\text { Decrease livestock } \\
\text { growth rates, causes } \\
\text { infections }\end{array}$ & Govere et al. (2007) \\
\hline \multirow{2}{*}{$\begin{array}{l}\text { Medicinal and cosmetic } \\
\text { products }\end{array}$} & $\begin{array}{l}\text { Anti-inflammatory drug } \\
\text { (Diclofenac) }\end{array}$ & $\begin{array}{c}\text { Reduction in microbial } \\
\text { biodiversity, negative } \\
\text { influence on living } \\
\text { systems }\end{array}$ & Primožič et al. (2020) \\
\hline & $\begin{array}{l}\text { Disinfecting soaps } \\
\quad \text { (Triclosan) }\end{array}$ & $\begin{array}{l}\text { Contributes to bacterial } \\
\text { resistance to antibiotics }\end{array}$ & Li et al. (2016) \\
\hline \multirow{3}{*}{ Textile manufacturing } & Azo dyes & $\begin{array}{l}\text { Carcinogenic, mutagenic, } \\
\text { affects photosynthetic } \\
\text { processes }\end{array}$ & Parveen et al. (2020) \\
\hline & Anthraquinone dyes & Carcinogenic, mutagenic & Bilal et al. (2017b) \\
\hline & $\begin{array}{c}\text { Industrial textile effluent } \\
\text { (dyes mixture) }\end{array}$ & $\begin{array}{l}\text { Carcinogenic, mutagenic, } \\
\text { genotoxic }\end{array}$ & Bilal et al. (2016) \\
\hline $\begin{array}{l}\text { Food industry } \\
\text { (distillery waste) }\end{array}$ & Melanoidins & $\begin{array}{l}\text { Diabetes mellitus, } \\
\text { cardiovascular } \\
\text { complications, } \\
\text { Alzheimer's disease }\end{array}$ & $\begin{array}{c}\text { Kumar \& Chandra } \\
\text { (2020); Somoza (2005) }\end{array}$ \\
\hline
\end{tabular}




\section{Table 2}

Advantages, limitations and development stage of different treatment processes.

\begin{tabular}{|c|c|c|c|c|c|}
\hline Treatment process & Description & Development phase & Advantages & Limitations & References \\
\hline \multicolumn{6}{|l|}{ Physical methods } \\
\hline Adsorption & $\begin{array}{l}\text { Recovery process } \\
\text { allowing the selective } \\
\text { concentration of } \\
\text { pollutants on the } \\
\text { surface of adsorbent } \\
\text { materials }\end{array}$ & Full-scale & $\begin{array}{ll}\checkmark & \text { Fast kinetics with } \\
& \text { good removal } \\
\text { efficiency } \\
\checkmark & \text { Treatment adapted to } \\
\text { different } \\
\text { configurations }\end{array}$ & $\begin{array}{l}\times \quad \text { High cost related to the } \\
\text { regeneration or disposal } \\
\text { of used adsorbent } \\
\times \quad \text { Pollution transfer from } \\
\text { one phase to another } \\
\text { without destruction }\end{array}$ & (Crini et al., 2019) \\
\hline $\begin{array}{c}\text { Membrane separation } \\
\text { processes }\end{array}$ & $\begin{array}{l}\text { The preferential } \\
\text { passage of one species } \\
\text { among others between } \\
\text { two compartments by } \\
\text { change in } \\
\text { concentration gradient } \\
\text { through a selective } \\
\text { barrier }\end{array}$ & Full-scale & $\begin{array}{l}\text { Possibility to recover } \\
\text { and reuse water and } \\
\text { the desired product } \\
\checkmark \text { Availability of various } \\
\text { membrane } \\
\text { geometries with wide } \\
\text { field of application: } \\
\text { clarification, } \\
\text { production of pure } \\
\text { water }\end{array}$ & $\begin{array}{ll}\times & \text { High energy requirements } \\
\times & \text { Membrane clogging } \\
\times & \text { Disposal issue of } \\
& \text { concentrated sludge }\end{array}$ & $\begin{array}{l}\text { (Ezugbe \& } \\
\text { Rathilal, 2020) }\end{array}$ \\
\hline Ion exchange & $\begin{array}{l}\text { The technique is based } \\
\text { on the reversible } \\
\text { exchange of ions } \\
\text { between insoluble } \\
\text { macromolecules (resin) } \\
\text { with other ions of } \\
\text { similar charges present } \\
\text { in the solution } \\
\text { surrounding the solid }\end{array}$ & Full-scale & $\begin{array}{ll} & \text { Simple technology, } \\
\text { tested and easy to } \\
\text { control } \\
\checkmark \text { Adapted to the } \\
\text { concentration of } \\
\text { metals and minerals } \\
\checkmark \text { Effective at low metal } \\
\text { levels (ppb) }\end{array}$ & 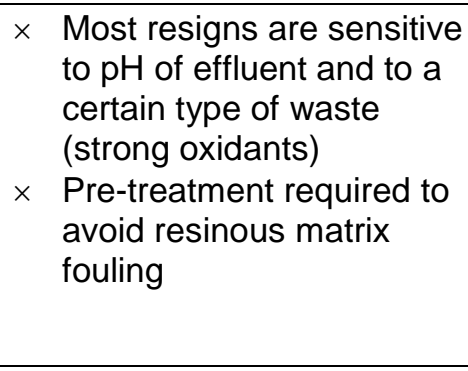 & $\begin{array}{l}\text { (Fu \& Wang, } \\
\text { 2011; Sonune \& } \\
\text { Ghate, 2004) }\end{array}$ \\
\hline
\end{tabular}


Table 2 (continued)

\begin{tabular}{|c|c|c|c|c|c|c|}
\hline \multicolumn{7}{|l|}{ Chemical methods } \\
\hline Photocatalytic oxidation & $\begin{array}{l}\text { The generation of } \\
\text { highly reactive oxidizing } \\
\text { species }\left(\bullet \mathrm{OH} \text { or } \bullet \mathrm{O}_{2}^{-}\right) \\
\text {initially induced by } \\
\text { activation of a } \\
\text { photocatalytic nature } \\
\text { leads to the oxidation of } \\
\text { organic pollutants into } \\
\text { non-toxic mineral } \\
\text { species. }\end{array}$ & Pilot-scale & $\begin{aligned} \checkmark & \text { Rapid and efficient } \\
& \text { degradation kinetics } \\
& \text { against recalcitrant } \\
& \text { molecules } \\
\checkmark & \text { No sludge production } \\
\checkmark & \text { Possibility of } \\
& \text { operating using solar } \\
& \text { energy }\end{aligned}$ & $x$ & $\begin{array}{l}\text { Formation of undesirable } \\
\text { by-products } \\
\text { Significant economic cost } \\
\text { relating to the synthesis of } \\
\text { the catalyst, its } \\
\text { regeneration and the use } \\
\text { of UV lamps }\end{array}$ & $\begin{array}{l}\text { (Crini \& } \\
\text { Lichtfouse, 2019) }\end{array}$ \\
\hline Electro-oxidation & $\begin{array}{l}\text { The electrochemical } \\
\text { oxidation of organic } \\
\text { compounds takes place } \\
\text { according to two } \\
\text { fundamental ways, } \\
\text { direct (at the surface of } \\
\text { the electrode) or } \\
\text { indirect (through active } \\
\text { species produced at } \\
\text { the electrode) }\end{array}$ & Pilot-scale & $\begin{array}{ll}\checkmark & \text { Improves the } \\
\text { biodegradability of } \\
\text { organic contaminants } \\
\checkmark \text { No need of pH } \\
\text { adjustment } \\
\checkmark \text { Adapted to large } \\
\text { volumes at different } \\
\text { flow rates }\end{array}$ & $x$ & $\begin{array}{l}\text { Anode passivation and } \\
\text { sludge deposition } \\
\text { High cost of energy } \\
\text { consumption } \\
\text { Generation of hazardous } \\
\text { materials, in particular } \\
\text { halogenated products }\end{array}$ & (Chen, 2004) \\
\hline Ozonation & $\begin{array}{l}\text { Ozone reacts with the } \\
\text { different contaminants } \\
\text { by direct oxidation } \\
\text { using molecular ozone } \\
\text { which involves } \\
\text { selective reactions with } \\
\text { low rates, and indirect } \\
\text { mechanism through } \mathrm{OH} \\
\text { radicals (non-selective } \\
\text { and highly reactive) } \\
\text { produced by the } \\
\text { decomposition of ozone }\end{array}$ & Full-scale & $\begin{array}{l}\checkmark \text { Easy production of } \\
\text { ozone from air or } \\
\text { oxygen by electric } \\
\text { discharge } \\
\checkmark \quad \text { Multiple applications } \\
\text { (disinfection, } \\
\text { reduction of odor, } \\
\text { chemical oxygen } \\
\text { demand and turbidity) }\end{array}$ & $x$ & $\begin{array}{l}\text { Incomplete and partial } \\
\text { mineralization of } \\
\text { refractory organic } \\
\text { compounds } \\
\text { Short half-life for only } 20 \\
\text { min } \\
\text { On-site ozone generation } \\
\text { is necessary due to its } \\
\text { instability }\end{array}$ & $\begin{array}{l}\text { (Mecha \& } \\
\text { Chollom, 2020) }\end{array}$ \\
\hline
\end{tabular}


Table 2 (continued)

\begin{tabular}{|c|c|c|c|c|c|c|}
\hline \multicolumn{7}{|l|}{$\begin{array}{l}\text { Physico-chemical } \\
\text { treatment }\end{array}$} \\
\hline $\begin{array}{l}\text { Coagulation- } \\
\text { Flocculation }\end{array}$ & $\begin{array}{l}\text { Chemical coagulation } \\
\text { and flocculation cause } \\
\text { a change in the } \\
\text { physical state of } \\
\text { constituents dissolved } \\
\text { or suspended in water, } \\
\text { in order to facilitate } \\
\text { their removal by } \\
\text { sedimentation }\end{array}$ & Full-scale & $\begin{array}{l}\text { Very widespread use } \\
\text { of the process } \\
\text { (equipment and } \\
\text { chemical agents } \\
\text { available) } \\
\checkmark \text { Stable system } \\
\text { adapted to } \\
\text { temperature, load and } \\
\text { flow variations) } \\
\checkmark \text { Significant reduction } \\
\text { of phosphorus and } \\
\text { nitrogen }\end{array}$ & $x$ & $\begin{array}{l}\text { The addition of the } \\
\text { coagulant can be complex } \\
\text { and require continuous } \\
\text { adjustment depending on } \\
\text { the effluent composition } \\
\text { Production of a large } \\
\text { sludge volume } \\
\text { The toxicity of the sludge } \\
\text { produced requires } \\
\text { treatment before disposal, } \\
\text { which results in an } \\
\text { additional cost to the } \\
\text { process }\end{array}$ & (Jiang, 2015) \\
\hline \multicolumn{7}{|l|}{ Biological methods } \\
\hline $\begin{array}{l}\text { Activated sludge } \\
\text { process }\end{array}$ & $\begin{array}{l}\text { In an aerobic } \\
\text { environment, the } \\
\text { microbial culture breaks } \\
\text { down organic } \\
\text { contaminants and } \\
\text { forms a biological floc } \\
\text { in suspension, and } \\
\text { consequently a gradual } \\
\text { clarification of the water }\end{array}$ & Full-scale & $\begin{array}{ll}\checkmark & \text { Process suitable for } \\
\text { high organic loads } \\
\checkmark \text { Process adapted to } \\
\text { the intensive } \\
\text { treatment of } \\
\text { phosphorus } \\
\checkmark \text { Limited land holdings }\end{array}$ & $\begin{array}{l}x \\
x\end{array}$ & $\begin{array}{l}\text { High operating cost } \\
\text { especially for small } \\
\text { installations } \\
\text { Rigorous maintenance } \\
\text { Substantial sludge } \\
\text { production }\end{array}$ & $\begin{array}{l}\text { (Crini \& } \\
\text { Lichtfouse, 2019) }\end{array}$ \\
\hline Algae decomposition & $\begin{array}{l}\text { The algal cell absorbs } \\
\text { and transforms organic } \\
\text { and inorganic } \\
\text { compounds into nucleic } \\
\text { acids and proteins for } \\
\text { the growth of algal } \\
\text { biomass }\end{array}$ & Pilot/large-scale & $\begin{aligned} & \checkmark \text { Low energy } \\
& \text { consumption due to } \\
& \text { its autotrophy } \\
& \checkmark \text { Nontoxic detoxifying } \\
& \text { agent } \\
& \checkmark \text { Ability to fix carbon } \\
& \text { dioxide present in the } \\
& \text { ambient environment }\end{aligned}$ & $x$ & $\begin{array}{l}\text { Difficulty in harvesting } \\
\text { and separating algae } \\
\text { biomass } \\
\text { Ineffective against micro- } \\
\text { pollutants } \\
\text { Reduced performance in } \\
\text { cold climates }\end{array}$ & $\begin{array}{l}\text { (Lavrinovičs \& } \\
\text { Juhna, 2018) }\end{array}$ \\
\hline
\end{tabular}


Table 2 (continued)

\begin{tabular}{|c|c|c|c|c|c|}
\hline Enzyme technology & $\begin{array}{l}\text { Enzymes extracted } \\
\text { from microorganisms } \\
\text { and plants lower the } \\
\text { activation energy and } \\
\text { facilitate the rapid and } \\
\text { complete breakdown of } \\
\text { organic compounds }\end{array}$ & Pilot-scale & $\begin{array}{ll}\checkmark & \text { Rapid, cost effective } \\
& \text { and highly specific } \\
\checkmark & \text { Safe and eco-friendly } \\
\checkmark & \text { Can be applied to a } \\
& \text { large range of } \\
& \text { different compounds } \\
\text { in mixture }\end{array}$ & $\begin{array}{l}\times \text { Limitations on the stability } \\
\text { and activity of enzymes } \\
\text { for multi-cycle use }\end{array}$ & (Bilal et al., 2021) \\
\hline
\end{tabular}




\section{Table 3}

Role and application of peroxidases from different sources.

\begin{tabular}{|c|c|c|c|c|}
\hline Family & Enzyme & Enzyme source & Role/Application & Reference \\
\hline \multirow{3}{*}{ Class I } & $\begin{array}{c}\text { Ascorbate peroxidase } \\
(A P X)\end{array}$ & - & $\begin{array}{l}\text { Scavenge and detoxify } \\
\text { reactive oxygen species } \\
\text { in plants }\end{array}$ & Ashraf (2009) \\
\hline & $\begin{array}{c}\text { Cytochrome c } \\
\text { peroxidase (Cyt c) }\end{array}$ & - & $\mathrm{H}_{2} \mathrm{O}_{2}$ biosensor & $\begin{array}{l}\text { Zhang et al. } \\
\text { (2019) }\end{array}$ \\
\hline & $\begin{array}{c}\text { Catalase-peroxidase } \\
\text { (CP) }\end{array}$ & Bacillus SF & $\begin{array}{l}\text { Treatment of textile- } \\
\text { bleaching effluents }\end{array}$ & $\begin{array}{l}\text { Fruhwirth et al. } \\
\qquad(\mathbf{2 0 0 2 )}\end{array}$ \\
\hline \multirow{6}{*}{ Class II } & \multirow[t]{2}{*}{$\begin{array}{l}\text { Lignin peroxidase } \\
\text { (LiP) }\end{array}$} & Pichia methanolica & $\begin{array}{c}\text { Degradation of } \\
\text { tetracycline, dibutyl } \\
\text { phthalate, 5-chlorophenol, } \\
\text { phenol, phenanthrene, } \\
\text { fluoranthene, } \\
\text { benzo(a)pyrene }\end{array}$ & Guo et al. (2019) \\
\hline & & $\begin{array}{l}\text { Ganoderma } \\
\text { lucidum IBL-05 }\end{array}$ & Dye decolorization & $\begin{array}{l}\text { Shaheen et al. } \\
(2017)\end{array}$ \\
\hline & \multirow{2}{*}{$\begin{array}{c}\text { Manganese } \\
\text { peroxidase }(\mathrm{MnP})\end{array}$} & Trametes sp.48424 & $\begin{array}{c}\text { Enzymatic transformation } \\
\text { of different dyes and } \\
\text { PAHs }\end{array}$ & $\begin{array}{l}\text { Zhang et al. } \\
\text { (2016) }\end{array}$ \\
\hline & & $\begin{array}{c}\text { Cerrena unicolor } \\
\text { BBP6 }\end{array}$ & $\begin{array}{l}\text { Decolorization of } \\
\text { anthraquinone, azo and } \\
\text { triphenylmethane dyes }\end{array}$ & $\begin{array}{l}\text { Zhang et al. } \\
\text { (2018) }\end{array}$ \\
\hline & \multirow[b]{2}{*}{$\begin{array}{l}\text { Versatile peroxidase } \\
\qquad(V P)\end{array}$} & $\begin{array}{c}\text { Lentinus } \\
\text { squarrosulus }\end{array}$ & $\begin{array}{l}\text { Crop residues } \\
\text { delignification }\end{array}$ & $\begin{array}{l}\text { Ravichandran et } \\
\text { al. (2019) }\end{array}$ \\
\hline & & Pleurotus eryngii & $\begin{array}{c}\text { Evans blue, guinea green } \\
\mathrm{B} \text { and amido black } 10 \mathrm{~B} \\
\text { degradation }\end{array}$ & $\begin{array}{l}\text { Ilić Đurđić et al. } \\
\qquad(2020)\end{array}$ \\
\hline \multirow{3}{*}{ Class III } & $\begin{array}{c}\text { Ginger peroxidase } \\
\text { (GP) }\end{array}$ & Ginger & $\begin{array}{c}\text { Degradation of Reactive } \\
\text { Blue } 4 \text { dye }\end{array}$ & Ali et al. (2018) \\
\hline & $\begin{array}{l}\text { Soybean peroxidase } \\
\text { (SBP) }\end{array}$ & $\begin{array}{l}\text { Soybean hulls } \\
\text { (Glycine max) }\end{array}$ & $\begin{array}{l}\text { Biodegradation of azo } \\
\text { dyes and carbamazepine }\end{array}$ & $\begin{array}{l}\text { Calza et al. } \\
\quad(\mathbf{2 0 1 6 )}\end{array}$ \\
\hline & $\begin{array}{c}\text { Horseradish } \\
\text { peroxidase (HRP) }\end{array}$ & Horseradish & Aflatoxin B1 removal & $\begin{array}{l}\text { Zhou et al. } \\
\text { (2019) }\end{array}$ \\
\hline
\end{tabular}




\section{CRedit authorship contribution statement}

Kheireddine Sellami: Conceptualization, Investigation, Writing-original draft.

Annabelle Couvert: Supervision, Funding acquisition, Writing-review \& editing.

Noureddine Nasrallah: Supervision, Funding acquisition.

Rachida Maachi: Supervision, Funding acquisition.

Mahmoud Abouseoud: Conceptualization, Supervision.

Abdeltif Amrane: Supervision, Funding acquisition, Writing-review \& editing. 
Declaration of interests

$\bigotimes$ The authors declare that they have no known competing financial interests or personal relationships that could have appeared to influence the work reported in this paper.

$\square$ The authors declare the following financial interests/personal relationships which may be considered as potential competing interests: 


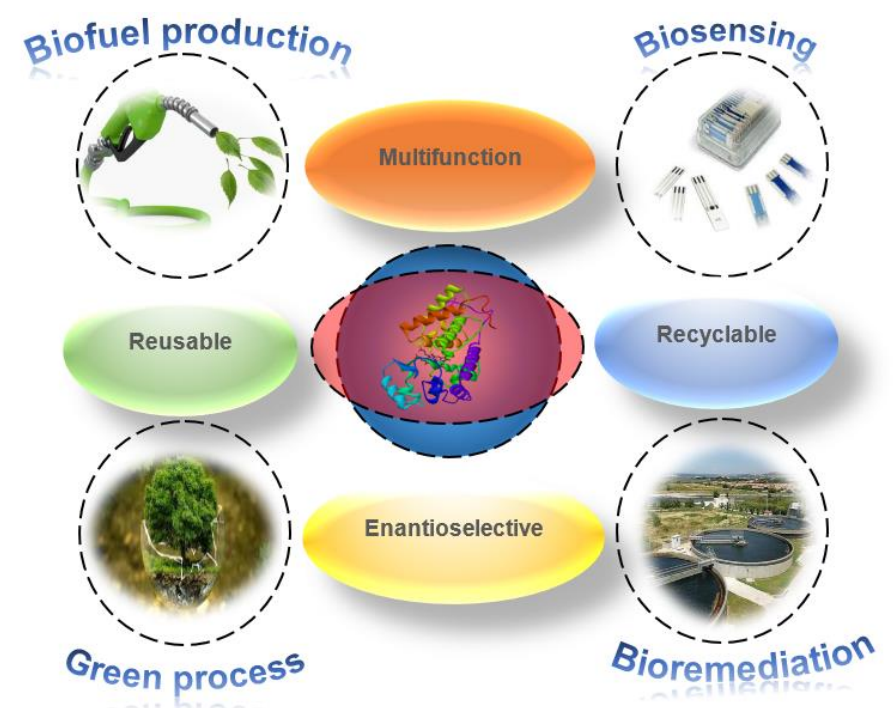

\section{Graphical abstract}




\section{Highlights}

- Peroxidases ability to catalyze oxidation of a broad spectrum of environmental pollutants.

- Mechanism of action and metabolites resulted from peroxidases applications are shown.

- Biocatalyst versatility is advanced for economical and profitable biotechnology applications. 